\title{
El pan y el vino en el judaísmo antiguo y medieval
}

\author{
Bread and Wine in the Ancient and Medieval Judaism
}

\author{
EnRIQUe Cantera Montenegro \\ UNED
}

\begin{abstract}
RESUMEN
En este trabajo se estudia la importancia que el pan y el vino tuvieron en la alimentación cotidiana de los judíos a lo largo de la Antigüedad y la Edad Media, así como el lugar que estos productos ocupan en el culto judío del Templo y en la liturgia de algunas de las más importantes celebraciones religiosas de carácter familiar. Los judíos, como todos los demás pueblos de civilización mediterránea, han basado tradicionalmente su agricultura en la llamada tríada mediterránea - cereal, vid y olivo-, lo que se refleja en su alimentación cotidiana, que se sustenta, en buena medida, en el consumo de pan y vino. Del mismo modo, desde la Antigüedad tardía y hasta tiempos actuales, el pan y el vino son elementos fundamentales en la celebración familiar de algunas de las principales festividades del calendario litúrgico judío, en particular el Sábado (Shabat) y la Pascua (Pésah).
\end{abstract}

\section{PALABRAS CLAVE}

Pan, vino, judíos, judaísmo, Biblia, Torá, Talmud, alimentación cotidiana, liturgia,

Shabat, séder, Pésah, matzot, quidús, kasher, «vino judiego».

\section{ABSTRACT}

In this work is studied the importance that bread and wine had in the daily feeding of the Jews throughout the Antiquity and in the Middle Ages, as well as the role that these products played in the Jewish cult of the Temple and in the liturgy of some of the most important familiar religious celebrations. The Jews, like all the other peoples of Mediterranean civilization, have traditionally based their agriculture on the Mediterranean Triad - cereal, grapevine and olive tree-, that is reflected in their daily feeding, that sustains themselves, to a great extent, in bread and wine consumption. Thus, from the late Antiquity to now, bread and wine are fundamental elements in the family celebrations of some of the main festivities of the Jewish Liturgical Calendar, in particular, the Saturday (Shabat) and the Passover (Pésah).

\section{KEY WORDS}

Bread, Wine, Jewish, Judaism, Bible, Torah, Talmud, daily feeding, Liturgy, Sabbath, séder, Pésah, matzot, quidús, kasher, «jewish wine». 
El judaísmo ha considerado siempre al cereal y al vino entre los productos agrícolas más importantes, con una significación muy especial tanto en la alimentación cotidiana como en el culto y en las fiestas religiosas y profanas. De este modo el pan y el vino, con sus correspondientes bendiciones ${ }^{1}$, han sido a lo largo de la historia para los judíos elementos esenciales de la comida cotidiana, y ocupan un lugar especialmente relevante en la liturgia de acogida y de despedida del shabat ${ }^{2}$, así como en las celebraciones familiares propias de algunas de las principales festividades del calendario litúrgico judío, de forma muy especial por lo que respecta a la celebración del séder ${ }^{3}$ de Pascua (Pésah).

\section{EL PAN Y EL VINO EN EL JUDAÍSMO EN TIEMPOS BÍBLICOS}

En la Antigüedad, Palestina era una tierra próspera desde el punto de vista agrícola. Su clima mediterráneo propiciaba una agricultura a base, principalmente, de cereal, vid y olivo, y un paisaje vegetal que tenía sus elementos más característicos en la vid, el olivo y la higuera. La disposición de trigo, vino nuevo y aceite en cantidad suficiente es considerada en la Biblia un signo de abundancia y una bendición divina, como anuncia el patriarca Isaac a su hijo preferido:

«Dios te dé, del rocío del cielo y de la grosura de la tierra, abundancia de trigo $y$ de vino" 4 ,

y como promete Yahvé al pueblo de Israel, por boca de Moisés, si permanece fiel a sus mandamientos:

"Si obedeciereis, pues, a mis mandamientos, que yo hoy os intimo, amando al Señor Dios vuestro y sirviéndole de todo vuestro corazón, y de toda vuestra alma, dará a vuestra tierra la lluvia temprana y tardía, para que cojáis trigo, y vino, y aceite» ${ }^{5}$.

En definitiva, la Tierra Prometida es representada con frecuencia en los libros bíblicos, conforme a la promesa divina, como un país de trigo y de vino nuevo, que por entonces constituían la imagen de la riqueza.

\footnotetext{
${ }^{1}$ La Torá señala la obligación de alabar y dar gracias a Dios por la comida. El Talmud amplió este concepto en el sentido de que el mundo entero pertenece a Dios y el hombre no tiene derecho a disfrutarlo sin pedirle permiso; así, las diversas bendiciones (berakot) recitadas por todo judío que disfruta de algún placer son, en realidad, peticiones de permiso para hacerlo. Muchas bendiciones fueron compuestas para ser recitadas antes de aceptar diversos placeres, en especial la comida y la bebida. El pan y el vino tienen una bendición propia y específica, distinta a la de otros productos agrícolas, lo que es una señal inequívoca de la importancia que se les concede en el judaísmo, ya desde los tiempos bíblicos.

${ }^{2}$ Día que pone fin a la semana en el calendario judío. En rememoración del descanso de Yahvé tras la creación del mundo, es un día consagrado al descanso y a la meditación.

${ }^{3}$ Así se denomina a la cena ritual que los judíos celebran la primera noche de la fiesta de Pésah (Pascua), y que va acompañada de diversas recitaciones, cánticos, bendiciones, aleluyas y otras plegarias, así como del relato de la hagadá de Pésah. Los principales componentes de la cena son las matzot (tortas de pan ázimo), el maror (verduras amargas), el haroset (mixtura a base de frutas, canela, miel y vino), el vino y el cordero asado, que guardan un profundo significado en relación con la última cena de los israelitas antes de la salida de Egipto.

4 Génesis, XXVII, 28.

${ }^{5}$ Deuteronomio, XI, 13-14.
} 


\section{El pan en el primitivo Judaísmo}

Además de su finalidad primordialmente alimenticia, el pan tenía también en el Israel de los tiempos bíblicos un componente sacrificial, de forma que en la Torá se hace alusión a los «panes de la proposición» o «de la presentación» y a los «panes de las primicias». Los «panes de la proposición» (léjem panim) ${ }^{6}$ son las doce tortas hechas de flor de harina que eran «propuestas» 0 «presentadas» a Yahvé sobre el Arca de la Alianza (Aron ha-berit) ${ }^{7}$, que se ubicaba en el Tabernáculo, junto con el candelabro de siete brazos, también de oro; tras la construcción del Templo de Jerusalén, la mesa de los panes se ubicaba dentro del recinto del Templo9. Los «panes de la proposición» eran ofrecidos «ante la Faz de Yahvé», motivo por el que también eran denominados «panes de la Faz». Asimismo eran conocidos como "panes de la fila» o "de la pila», ya que se disponían en dos filas o pilas de seis, depositándose incienso sobre cada pila. Los panes se renovaban cada sábado, y sólo podían ser consumidos por los sacerdotes ${ }^{10}$.

Los «panes de las primicias»" ${ }^{11}$ eran aquellos que los campesinos ofrendaban en el Templo en señal de agradecimiento por la cosecha ${ }^{12}$. La Ley mosaica ordenaba a los israelitas ofrecer a Dios los primeros frutos de la tierra, en reconocimiento por la Tierra Prometida que habían obtenido de Él, así como en acción de gracias por los bienes recibidos ${ }^{13}$. Esta costumbre, originariamente voluntaria, se convirtió más tarde en obligatoria, regulándose e incrementándose las cantidades que debían ser ofrendadas de los principales frutos de la cosecha: trigo, cebada, uvas, higos, granadas, dátiles y aceitunas. La ofrenda se realizaba en el santuario, y debe interpretarse, probablemente, como un sacrificio, del que la mayor y la mejor parte se entregaba a los sacerdotes; en este sentido, el código sacerdotal ve en la ofrenda de las primicias una contribución a favor del sacerdote ${ }^{14}$. En concreto por lo que respecta al pan, los holocaustos en el Templo, excepto cuando eran para ser consumidos, se hacían con pan sin levadura, ya que ésta se consideraba como agente de fermentación y, por tanto, de putrefacción ${ }^{15}$. Estas ofrendas se re-

${ }^{6}$ André-Marie GERARD y Andrée NORDON-GERARD (con la colaboración del P. Tollu), Diccionario de la Biblia. Madrid. Anaya \& Mario Muchnik, 1995, voz «Panes de la Proposición», págs. 1139-1140.

${ }^{7}$ Según la descripción que se hace en Éxodo, XXXVII, 1-9, el Arca consistía en un armario de madera de acacia, de dos codos y medio de largo, un codo y medio de ancho y un codo y medio de alto, revestido de oro por dentro y por fuera. En ella se guardaban las Tablas de la Ley.

${ }^{8}$ Lugar santo, consistente en el centro del santuario presalomónico. El Tabernáculo estaba dividido en el santo, donde se encontraban la mesa de los panes de la proposición, el candelabro de siete brazos y el altar de los perfumes, y el santísimo, donde se guardaba el Arca; ambos espacios estaban separados mediante una cortina.

${ }^{9}$ Éxodo, XXV, 23-30 y XXXVII, 10-16; Números, IV, 7.

10 Levítico, XXIV, 1-9.

${ }^{11}$ Véase H. HAAG - A. VAN DEN BORN - S. de AUSEJO, Diccionario de la Biblia. Barcelona. Editorial Herder, 1964, voz «Primicias», columna 1567.

12 Levítico, XXIII, 20; 2 Reyes, IV, 42.

${ }^{13}$ Éxodo, XXII, 28, XXIII, 19 y XXXIV, 26; Deuteronomio, XVIII, 4 y XXVI, 1-11.

${ }^{14}$ Números, XV, 17-21 y XVIII, 12; Levítico, XIX, 24 y XXIII, 9-20.

${ }^{15}$ El Levítico, XXIII, 17, recoge la obligación de ofrecer en el Templo dos panes hechos con el trigo nuevo. 
alizaban en el Templo con ocasión de la celebración de la festividad de Shavuot, que tiene lugar el día 6 del mes de siván ${ }^{16}$, a las siete semanas o en el día quincuagésimo (Pentecostés) de la celebración de Pésah. Shavuot era en sus orígenes una fiesta agrícola, la fiesta de las primicias, pero tras la destrucción del Segundo Templo de Jerusalén (70 d.C.) se transformó en una fiesta de carácter histórico, en la que se actualizaba la revelación de la Ley a Moisés en el Monte Sinaí.

El pan adquirió también en el antiguo Israel un marcado simbolismo, de forma que este término se utiliza con frecuencia en la Biblia en sentido metafórico. Así, si en el libro de los Proverbios se utiliza la imagen del pan como alegoría de la Sabiduría:

«La Sabiduría edificó su casa, talló siete columnas.

Sacrificó sus víctimas, mezcló su vino, y también preparó su mesa.

Envió sus doncellas gritando en lo más alto de las alturas de la ciudad:

'Quien sea sencillo, que venga aquí. Al falto de seso le dice:

'Venid, comed participando de mi pan, y bebed participando del vino que he mezclado.

Abandonad la simpleza y viviréis; $y$ andad por el camino de la inteligencia» ${ }^{17}$, y en el Eclesiástico se habla del «pan de la inteligencia» y del «agua de la sabiduría»:

«El que teme a Dios hará bienes, y el que tiene en sí la justicia echará mano de ella,

Y le saldrá ella al camino como madre honrada, y lo recibirá como una esposa virgen.

Lo alimentará con pan de vida y de entendimiento, y agua de sabiduría de salud le dará a beber, y se afirmará en él, y él no se doblegarás 18,

en los Salmos, cuando el profeta ruega al Señor que otorgue la libertad a su pueblo, expresando la desolación de Israel bajo la figura de una viña arruinada, se representa el juicio divino como el «pan de lágrimas»:

« ¿Nos alimentarás con pan de lágrimas, y nos darás bebida de lágrimas con medida?» ${ }^{19}$

Con un trasfondo más popular, «comer el pan» con alguien sería sinónimo de una comida de alianza o de un banquete:

«E inmoladas las víctimas en el monte, (Jacob) llamó a sus hermanos para que comiesen pan. Los cuales, después de haber comido, se quedaron allir» ${ }^{20}$.

\footnotetext{
${ }^{16}$ Noveno mes del calendario civil judío, y tercero del litúrgico. Tiene treinta días, y su comienzo oscila entre el 11 de mayo y el 9 de junio.

17 Proverbios, IX, 1-6.

18 Eclesiástico, XV, 1-3.

${ }^{19}$ Salmos, LXXX, 6.

${ }^{20}$ Génesis, XXX, 54.
} 


\section{El vino y la viticultura en la Biblia}

Las referencias bíblicas al vino y a la viticultura son también muy numerosas ${ }^{21}$; la primera de todas ellas es la que se contiene en el capítulo IX del libro del Génesis, en el que se narra cómo Noé plantó una viña y se embriagó al consumir vino, pues desconocía sus efectos etílicos. Las frecuentes alusiones al vino y a la viticultura en la Torá son una señal evidente de que el vino era una bebida conocida y muy apreciada en tiempo de los Patriarcas, tanto en Israel como en las regiones próximas. Así, el Deuteronomio retrata a Palestina, la Tierra Prometida para los judíos, como una

«tierra pródiga en trigo, cebada, viñas, higueras y granados; tierra de olivares, de aceite y de miel; tierra que te brindará pan sin escasez»"22.

Entre los vinos más afamados, los libros bíblicos citan el del valle del Líbano'3; el de Jelbón, junto a Damasco ${ }^{24}$; el de En-Guedí, en el desierto de Judá25; y el del valle de Escol, junto a Hebrón, cuyo nombre derivaría, precisamente, de las uvas que allí se cultivaban:

"Y llegaron hasta el valle de Escol y cortaron allí una rama de vid con racimos de uvas, que llevaron entre dos por medio de una pértiga, y también granadas e higos. Ese lugar fue llamado valle de Escol, por causa del sarmiento (escol) que se Ilevaron los hijos de Israel»"26.

Así, pues, el vino era la bebida alcohólica más apreciada en los tiempos bíblicos. Tenía la consideración, a un mismo tiempo, de un alimento, de un producto excitante y de una bebida ritual. Son muy numerosos los pasajes bíblicos en los que se alaban las virtudes del vino como producto que alegra al hombre y que le permite olvidar las tristezas, de forma que si el libro de los Proverbios sentencia,

«Dadle licores fuertes al que está por perecer, y vino al que tiene el alma amargada. Beba él y olvide su pobreza, y no se acuerde más de su miseria» ${ }^{27}$,

los Salmos afirman de Dios que

"(Eres el) que hace que crezca la hierba para el ganado, y la verdura para el servicio del hombre, y el grano para sacar el pan de la tierra, y el vino que alegra el

\footnotetext{
${ }^{21}$ Sigo en este apartado, principalmente, las indicaciones que se recogen en $\mathrm{H}$. HAAG - A. VAN DEN BORN - S. de AUSEJO, Diccionario de la Biblia, voz «vino», columnas 2040-2043, y en André-Marie GERARD y Andrée NORDON-GERARD, Diccionario de la Biblia, voz «vino», págs. 1471-1473, y voz «viña», págs. 1473-1474.

${ }^{22}$ Deuteronomio, VIII, 8-9.

${ }^{23}$ Oseas, XIV, 8.

${ }^{24}$ Ezequiel, XXVII, 18.

${ }^{25}$ El Cantar de los Cantares, I, 14.

${ }^{26}$ Números, XIII, 23-24.

${ }_{27}$ Proverbios, XXXI, 6-7. Acerca de las referencias al vino en el libro de los Proverbios, véase Libro de los Proverbios del Antiguo Testamento. Edición de Jesús Cantera Ortiz de Urbina. Madrid. Ediciones Akal, col. «Akal Oriente», 2006 (véase pág. 20, «El vino en el libro de los Proverbios»).
} 
corazón del hombre, poniéndole el rostro más brillante que el aceite, y el pan que fortalece el corazón del hombre» ${ }^{28}$,

y el libro de los Jueces llega a decir que el vino alegra a Dios y a los hombres:

"Y los árboles le dijeron a la vid: 'Reina tú sobre nosotros'; mas la vid les replicó: '¿Debo acaso dejar mi vino, que alegra a Dios y al hombre, para ir a ondular sobre los árboles?'»29.

No menos significativo es el hecho de que entre las manifestaciones de las bendiciones y de los castigos de Yahvé al pueblo de Israel se citen con frecuencia la abundancia o la escasez, respectivamente, de la cosecha de vino. Dice a este respecto el libro de los Proverbios:

«Honra al Eterno con tu sustancia, y con los primeros frutos de todas tus ganancias. De tal modo habrá abundancia en tus graneros y tus lagares rebosarán de vino nuevo»30.

En sentido contrario, el Deuteronomio recoge la advertencia de Yahvé a su pueblo en el caso de que no atienda su palabra:

«Podrás plantar viñas, pero no beberás el vino. No podrás amontonar nada, porque lo comerán los gusanos» ${ }^{31}$.

Como es también fácil deducir de diversos pasajes bíblicos, la viticultura conoció un alto grado de desarrollo en el antiguo Israel. Las viñas ocupaban, preferentemente, las lomas y las laderas suaves de valles fértiles, que eran muy apropiadas para el cultivo de la vid. Antes de proceder a la plantación de una viña, los cultivadores procedían a remover y a despedregar el terreno:

«Dejadme cantar del amigo mío el canto de mi amigo a su viña. Mi amigo tenía una viña en un collado muy fértil. Y lo cavó, y lo limpió de piedras, y plantó la viña más escogida, y construyó una torre en medio de ella, y también hizo allí un lagar. Y se preocupó de que la viña diera uvas, pero le dio uvas salvajes. Y ahora -oh moradores de Jerusalén y hombres de Judá- juzgad, os lo ruego, entre yo y mi viña. ¿Qué pude haber hecho a la viña más de lo que he hecho? Mas cuando esperaba que diese uvas las dio silvestres. Y os diré ahora lo que haré con mi viña. Le quitaré el cerco, que será comido. Derribaré la estacada, que será hollada. La convertiré en una desolación. No será podada ni labrada. Y subirán los zarzas y los espinos» ${ }^{32}$.

De este pasaje se deduce también que, en ocasiones, las viñas se protegían del ganado doméstico y de los animales salvajes mediante cercas vegetales o va-

\footnotetext{
28 Salmos, CIV, 14-15.

${ }^{29}$ Jueces, IX, 12-13.

30 Proverbios, III, 9-10.

${ }^{31}$ Deuteronomio, XXVIII, 39.

32 Isaías, V- 1-6.
} 
llas de madera. Del mismo modo, no debía ser infrecuente su cultivo en forma de parral, o viña alta, de forma que los sarmientos trepaban por estacas o cañas clavadas en el suelo o, incluso, por el tronco de higueras, de donde procede la expresión, bastante frecuente en los libros bíblicos, de «habitar bajo su viña y su higuera». Así, dice el profeta Zacarías:

«En ese día, dice el Eterno de los ejércitos, llamaréis a cada hombre vuestro vecino bajo la viña y bajo la higuera»33,

y señala el profeta Miqueas:

«Y Él juzgará entre muchos pueblos, y decidirá sobre naciones poderosas distantes. Y fundirán sus espadas y las convertirán en arados, y sus lanzas en hoces. No levantará más nación alguna espada contra otra nación, ni aprenderán más la guerra, sino que cada hombre se sentará bajo su vid y bajo su higuera, y nadie les asustará, porque la boca del Eterno de los ejércitos lo ha dicho» ${ }^{34}$.

Tras la vendimia, los racimos se trasladaban al lagar, con frecuencia excavado en el terreno y muy próximo a la viña; de este modo se aseguraba la rápida pisa de la uva, ya que su dilación en el tiempo podría dar lugar a su pérdida. Generalmente, el lagar estaba formado por dos planos en altura, comunicados entre sí; en el más alto se procedía a la pisa de la uva, en tanto que en el inferior se recogía el mosto. Una vez que el jugo había fermentado suficientemente, se trasegaba a odres - nével y nod en hebreo-, hechos a base de piel de borrego o de cabra, donde proseguía el proceso de fermentación. En definitiva, el proceso de elaboración del vino era muy similar en Israel al del antiguo Egipto.

Son numerosas las disposiciones de la Ley judía que protegían las vides y a sus cultivadores. Una de ellas castigaba al dueño de un rebaño que hubiera ramoneado una viña a indemnizar a su propietario con los frutos de su propia viña, calculados sobre la base de la mejor cosecha posible:

"Cuando alguien con su ganado dañare un campo o viña de otro, pagará restitución con lo mejor de su propio campo o de su propia viña» ${ }^{35}$.

En el capítulo XX del Deuteronomio, en el que se explicitan las leyes sobre la guerra, se exime de la obligación del servicio de armas a los campesinos que hubieran plantado una viña y que aún no hubieran tenido tiempo de recoger sus primeros frutos:

"¿Y qué hombre hay que haya plantado una viña y no haya comido todavía su fruto? Que también se vaya y vuelva a su casa, no sea que muera en la guerra y otro coma aquel fruto» ${ }^{36}$.

${ }^{33}$ Zacarías, III, 10.

${ }^{34}$ Miqueas, IV, 4.

${ }^{35}$ Éxodo, XXII, 4.

${ }^{36}$ Deuteronomio, XX, 6. 
Por otra parte, el Levítico prohibía a los dueños de las viñas racimar, es decir rebuscar los racimos que hubieran quedado en las viñas tras la vendimia, con el fin de que pudieran ser aprovechados por pobres y forasteros. Se trata de una medida de carácter social que, reiterada frecuentemente al pueblo hebreo, propició el afloramiento de sentimientos humanitarios:

" $Y$ cuando cosechareis lo sembrado en vuestras tierras, no segaréis hasta el límite de tu campo ni recogeréis las espigas caídas, ni rebuscarás tu viña ni recogerás el fruto caído de tu viña. Dejaréis todo eso para el pobre y para el forastero. Yo, el Eterno, vuestro Dios» ${ }^{37}$.

La Ley judía obligaba a que durante el año sabático o shemitá (en hebreo, "cada siete años»), todas las tierras de labor, y entre ellas las viñas, quedaran sin labrar y los frutos sin recoger, motivo por el que también se conocía al año sabático como «año de barbecho»:

"Y le dijo el Eterno a Moisés en el monte Sinaí: 'Diles a los hijos de Israel: Cuando lleguéis a la tierra que os di, la tierra descansará por el Eterno. Seis años la sembrarás y seis años podarás tu viña y recogerás su fruto, pero el séptimo año será de sábado ${ }^{38}$ estricto para la tierra y para el Eterno: ni sembrarás tu campo ni podarás tu viña. Lo que crezca espontáneamente de tu cosecha no lo recogerás y no vendimiarás tu viña silvestre. Será año de descanso para la tierra. $Y$ el descanso de la tierra será alimento para ti, para tu siervo, para tu sierva, para tu asalariado y para el forastero que habita contigo. Y para tus reses y para los demás animales de tu tierra esa producción se destinará a alimento» ${ }^{39}$.

Y la misma obligación se establecía para el año jubilar o yovel, que tiene lugar cada siete años sabáticos, es decir cada cincuenta años:

" $Y$ contarás siete sábados de años, o sea siete veces siete años, cuarenta y nueve años en total. Y el día diez del séptimo mes (del año quincuagésimo), día de la expiación ${ }^{40}$, harás resonar la trompeta en toda vuestra tierra ${ }^{41}$. Y santificaréis el año quincuagésimo y proclamaréis en toda la tierra la libertad de todos sus habitantes. Será año de jubileo para vosotros y devolveréis a cada hombre lo que le pertenece y devolveréis cada hombre a su familia. Es jubileo. Ese año no sem-

${ }^{37}$ Levítico, XIX, 9-10.

${ }^{38}$ Es decir, de descanso o de reposo (shabat significa textualmente en hebreo «descanso»).

${ }^{39}$ Levítico, XXV, 1-7.

40 Se refiere a la fiesta de Yom Kipur («Día del Perdón»), la más solemne del calendario litúrgico judío, dedicada al arrepentimiento y a la expiación de los pecados. Se celebra el día 10 del mes de tishri, primer mes del calendario civil hebreo y séptimo del litúrgico, y pone fin a los diez días de carácter penitencial que se inician el día de Rosh ha-shaná. Su celebración exige un ayuno riguroso y la abstención absoluta de toda actividad material, para dedicar el día por entero a la oración y a la meditación.

${ }^{41}$ Es el shofar, o especie de trompeta hecha con un cuerno de carnero vaciado, que se hace sonar en el curso de algunos oficios solemnes, especialmente en las festividades de Rosh ha-shaná y de Yom Kipur. En Yom Kipur, antes de concluir el oficio sinagogal nocturno (arbit o ma'arib), se hace sonar el shofar como anuncio del fin del ayuno y señal de que Dios ha escuchado las oraciones y ha otorgado el perdón de los pecados. 
braréis ni cosecharéis lo que haya crecido espontáneamente ni vendimiaréis vuestras viñas silvestres. Por ser jubileo ese año será sagrado para vosotros. Del campo comeréis su fruto. $Y$ ese año del jubileo devolveréis a cada cual su posesión. Y en toda venta o en toda compra que hicieres a tu prójimo no le engañarás. Comprarás a tu prójimo en proporción a la cantidad de años después del jubileo y él te venderá en proporción a la cantidad de años de su fruto. Conforme al número de años aumentarás o disminuirás el precio. No engañarás pues al prójimo, sino que temerás a tu Dios. Yo, el Eterno, tu Dios» ${ }^{42}$.

Tanto en el año sabático como en el año jubilar, los frutos nacidos de forma espontánea podían ser recogidos por el propietario de la tierra, o por otra persona cualquiera, si bien con la única finalidad de atender a las necesidades del sustento diario, y no para venderlos.

La importancia que el cultivo de la vid alcanzó en el antiguo Israel tiene también su reflejo en un lenguaje bíblico figurado, en el que Israel, el pueblo elegido, aparece bajo la imagen de una viña. Es así, por ejemplo, cuando los Salmos y los Profetas designan metafóricamente a Israel como una cepa o una viña que Dios ha trasplantado de Egipto a Canaán:

«Trajiste una vid de Egipto, expulsaste a las naciones y la plantaste. Limpiaste un sitio para ella, y echó raíces y llenó la tierra. Las montañas se cubrieron con su sombra, y los poderosos cedros con sus ramas. Extendió sus sarmientos hasta el mar, y sus renuevos hasta el río' ${ }^{43}$.

También los Salmos utilizan el símil de la viña abandonada o descuidada para expresar el castigo divino a Israel por sus infidelidades:

“¿Por qué derribaste sus vallados, de modo que la despojan todos los que pasan por el camino? La devasta el jabalí del bosque. Aliméntase de ella todo lo que se mueve en el campo. Oh Dios de los ejércitos, rogámoste vuelvas. Mira desde el cielo y ten consideración de esta vid, y del renuevo que plantó Tu diestra, y de la rama que fortaleciste ${ }^{44}$.

En otras ocasiones la vid es símbolo de paz, alegría y sabiduría (Eclesiástico, XXIV, 7), o representa a la mujer del hombre justo (Jeremías, XLVIII, 32), y con cierta frecuencia aparece asociada a las promesas de salvación mesiánica:

"Así dice el Eterno de los ejércitos: Aunque esto pareciere maravilloso ante los ojos del resto de este pueblo en aquellos días, ¿también será maravilloso ante mis ojos?, dice el Eterno de los ejércitos. Así dice el Eterno de los ejércitos: He aquí que he de salvar a mi pueblo del país del oriente, y del país del occidente, y los traeré y vivirán en medio de Jerusalén, y serán mi pueblo y yo seré su Dios, en verdad y en justicia. Así dice el Eterno de los ejércitos: Fortaleced vuestras manos, vo-

\footnotetext{
42 Levítico, XXV, 8-17.

43 Salmos, LXXX, 9-12.

${ }^{44}$ Salmos, LXXX, 13-16.
} 
sotros que oís en estos días aquellas palabras de boca de los profetas que había en el día en que puso el basamento de la Casa del Eterno de los ejércitos, el Templo, para que pudiese ser construido. Porque antes de esos días no se podía asalariar hombre ni bestia, ni había paz para el que salía o entraba por causa de su adversario, por cuanto Yo puse a todos los hombres el uno contra el otro. Pero ahora no seré para el resto de este pueblo como en aquellos días, dice el Eterno de los ejércitos. Porque como la simiente de la paz, la vid dará su fruto, y la tierra dará su producto, y el cielo dará su rocío, y Yo haré que el resto de este pueblo herede todas esas cosas. $Y$ sucederá que, así como fuisteis una maldición entre las naciones, oh Casa de Judá y Casa de Israel, así os he de salvar, y seréis una bendición. No temáis; dejad que vuestras manos se fortalezcan ${ }^{45}$.

Al igual que la vid, el vino es utilizado también frecuentemente en la Biblia con un sentido figurado. Así hace el profeta Isaías cuando compara los pecados de Sodoma y Gomorra con vino adulterado:

« ¡Cómo la ciudad fiel se ha tornado prostituta! Era plena de justicia, y la rectitud moraba en ella, pero ahora es refugio de homicidas. Tu plata se ha vuelto escoria. Tu vino está mezclado con agua» ${ }^{46}$,

o cuando, para expresar el castigo de Dios a los pueblos impíos, utiliza la imagen del que pisa las uvas en el lagar:

«¿Quién es éste que viene de Edom ${ }^{47}$, con vestidos rojos de Bozra? ¿Éste tan airoso en su traje, tan impresionante por su fuerza? Yo, que hablo en victoria, con poder para salvar. ¿Por qué es rojo tu traje, y tus ropas como las del que pisa el lagar? He pisado yo solo el lagar, y de los pueblos no había nadie conmigo, y entonces los pisé en mi ira, y los atrapé en mi indignación, y su sangre salpicó mis ropas, tiñéndose toda mi vestimenta. Porque el día de venganza que había en mi corazón y mi año de redención, han venido. Y miré, y no había nadie a quien ayudar. Y observé asombrado, y no había nadie a quien sostener. Por lo tanto mi propio brazo me trajo salvación, y mi ira me sostuvo. Y pisoteé los pueblos en mi ira, y los embriagué en mi indignación, y derramé su sangre sobre la tierra»48.

\section{El consumo de vino en el Judaísmo antiguo}

Como se ha indicado ya con anterioridad, en los tiempos bíblicos el vino ocupaba un lugar importante en la alimentación cotidiana, de forma que toda comida,

45 Zacarías, VIII, 6-13.

46 Isaías, I, 21-22.

${ }^{47}$ Edom era un pueblo semita que a fines del siglo XIV y principios del siglo XIII a.C. se estableció en la orilla sudoriental del Mar Muerto; su capital era la ciudad de Bosrá. En el período postbíblico, los idumeos (o edomitas) eran los habitantes de Idumea, un distrito administrativo situado al sur de Judea, cuya capital era la ciudad de Marissa. Cuando la región fue conquistada por Juan Hircano I (135/134-104 a.C.), etnarca de Judea y sumo sacerdote, los idumeos fueron obligados a convertirse al judaísmo. Desde la época talmúdica, el término Edom se utilizará para designar simbólicamente a Roma y al cristianismo.

${ }^{48}$ Isaías, LXIII, 1-6. 
desde la más sencilla a la más fastuosa, contaba con la presencia del vino, que corría abundantemente en las ceremonias nupciales y en los banquetes, como se describe en algunos de los festines bíblicos, como en el que el rey Asuero ${ }^{49}$ ofreció a todos sus príncipes y siervos, al ejército de Persia y de Media y a los nobles y príncipes de las provincias:

"Y les dieron de beber en copas de oro vino real en abundancia, de acuerdo con las riquezas del rey. Y la bebida fue brindada conforme a la ley, sin compulsión para nadie, por cuanto el rey había dispuesto que los funcionarios de su palacio vieran que cada cual hiciera según su propio gusto» ${ }^{50}$,

o en el banquete que ofreció a sus príncipes el rey Baltasar ${ }^{51}$ :

«Baltasar el rey ofreció una gran festín a mil de sus príncipes, y bebió vino ante los mil. Excitado por el vino, Baltasar ordenó que trajeran los vasos de oro y plata que Nabucodonosor, su padre, había sacado del Templo que estaba en Jerusalén, y que el rey y sus príncipes, sus mujeres y sus concubinas bebieran en ellos. $Y$ trajeron los vasos de oro que habían sido quitados de la Casa de Dios que estaba en Jerusalén, $y$ el rey y sus príncipes, sus mujeres y sus concubinas bebieron en ellos. Bebieron vino y alabaron los dioses de oro, y de plata, de bronce, de hierro, de madera y de piedra» ${ }^{52}$.

En la Antigüedad el vino era bastante fuerte, por lo que, para rebajar la acidez, era habitual consumirlo mezclado con agua, generalmente en una proporción de dos partes de agua por una de vino:

"Como el beber vino o sola agua no agrada, mientras que el vino mezclado con agua es suave y produce agradable deleite, así también la disposición agradable del relato es la que agrada a los oídos del lector, ${ }^{53}$.

Del mismo modo, y con el fin de mejorar su paladar, no era infrecuente que se mezclara con aromas y especias:

"La Sabiduría edificó su casa, talló siete columnas. Sacrificó sus víctimas, mezcló su vino, y también preparó su mesa. Envió sus doncellas gritando en lo más alto de las alturas de la ciudad: 'Quien sea sencillo, que venga aqui'. Al falto

\footnotetext{
${ }^{49}$ Rey persa (485-465 a.C.) que aparece citado en el libro de Ester, y que cabe identificar con Jerjes, hijo de Darío I Histaspes y padre de Artajerjes I Longimano. El carácter de Asuero en la narración de este libro coincide con la imagen que de él ofrecen los historiadores profanos, como Heródoto: más aventurero y caprichoso que príncipe esforzado.

${ }^{50}$ Ester, I, 7-8.

${ }^{51}$ Aunque los libros de Daniel y de Baruc lo presentan como último rey de los caldeos o babilonios, así como hijo de Nabucodonosor, lo cierto es que la historia profana no cita a ningún hijo de Nabucodonosor llamado Baltasar. Parece que era hijo del usurpador Nabonid, el último rey del nuevo imperio babilónico antes de que cayera en poder de los persas aqueménidas, y que fue corregente con su padre en Temá, importante ciudad caravanera situada al norte de Arabia. Fue asesinado en el año 539 a.C. con ocasión de la conquista de Babilonia por los persas.

${ }_{52}$ Daniel, V, 1-4.

${ }^{53} 2$ Macabeos, XV, 40.
} 
de seso le dice: 'Venid, comed participando de mi pan, y bebed participando de mi vino que he mezclado" 54 .

Aunque se consumía también vino blanco, existía predilección por el vino tinto, al que se refiere la expresión poética "sangre de uva». No era infrecuente que, para garantizar su mayor perdurabilidad, el vino se cociera, y que, para mejorar el aroma y el gusto, después de la pisa se dejaran reposar las heces durante largo tiempo, a lo que quizá hace referencia el profeta Jeremías cuando se refiere a los moabitas ${ }^{55}$ en los siguientes términos:

"Moab ha sido negligente desde su mocedad, y ha descansado sobre su sedimento, y no fue pasada de vasija en vasija, ni ha ido en cautiverio, por lo que le queda su sabor y su aroma no ha cambiado" ${ }^{56}$.

En definitiva, la Biblia, y de modo muy especial toda la literatura sapiencial, canta abundantemente las excelencias del vino bebido con moderación, resaltando su utilidad para hacer olvidar sus males al enfermo y la melancolía al triste:

«Dadle licores fuertes al que está por perecer, y vino al que tiene el alma amargada. Beba él y olvide su pobreza, y no se acuerde más de su miseria» ${ }^{57}$, aunque advierte de las malas consecuencias que acarrea el abuso de la bebida:

"No estés entre los bebedores de vino ni entre los glotones comedores de carne, porque el ebrio y el glotón irán a la pobreza, y la somnolencia vestirá al hombre con harapos» $\$ 8$.

Por este motivo, el consumo de vino y de licores estaba terminantemente prohibido a los sacerdotes cuando hubieran de entrar en el tabernáculo, para que no actuaran en el ministerio sagrado bajo sus efectos embriagadores:

"Y el Eterno le dijo a Aarón: 'No beberás vino ni licor, ni tampoco tus hijos contigo, cuando entréis al tabernáculo, para que no muráis. Será estatuto para todas vuestras generaciones, para que hagáis distinción entre lo sagrado y lo profano, y entre lo impuro y lo puro, y para que enseñéis a los hijos de Israel todos los estatutos que les dio el Eterno por intermedio de Moisés "59.

Asimismo se prohibía el vino a los dirigentes de la sociedad, para que no olvidaran las leyes y, consiguientemente, pudieran perjudicar de ese modo a los más débiles:

"No es para reyes, oh Lemuel, no es para reyes el beber vino, ni es para príncipes el decir: '¿Dónde está el licor fuerte?', no sea que beban y olviden lo que está decretado, y perviertan la justicia debida a los afligidos" 60 .

${ }_{54}$ Proverbios, IX, 1-5.

${ }^{55}$ Conjunto de tribus emparentadas con los israelitas. Originariamente nómadas, se establecieron hacia el siglo XIII a.C. al este del Jordán, entre el mar Muerto y el desierto siroarábigo.

${ }^{56}$ Jeremías, XLVIII, 11.

${ }^{57}$ Proverbios, $\mathrm{XXXI}, 6-7$.

58 Proverbios, XXIII, 20-21.

59 Levítico, X, 8-11.

60 Proverbios, XXXI, 4-5. 


\section{EL PAN Y EL VINO EN LA LITURGIA Y EN EL CULTO JUDÍOS}

Como se ha indicado ya anteriormente, el pan y el vino tienen una especial relevancia en la liturgia de acogida y de despedida del shabat y de algunas de las principales festividades del calendario litúrgico judío, así como en la celebración de la Pascua. Tras la destrucción del Templo de Jerusalén (70 d.C.), sus manifestaciones más señaladas son las que tienen lugar en las celebraciones familiares de estas fiestas.

\section{El pan en la celebración familiar de la cena de Shabat y del séder de Pésah}

Más allá del importante lugar que, como en toda civilización mediterránea, tenía el pan en la alimentación cotidiana de los judíos en la Antigüedad y el Medievo, la tradición hebrea le otorga un marcado simbolismo religioso, con su manifestación más significativa en la cena del viernes que da comienzo a la festividad del Shabat, y que tiene lugar al regreso del oficio sinagogal vespertino (minhá). Sobre una mesa cubierta con manteles limpios se deposita una copa de vino y dos panes, colocados en un plato y cubiertos con un paño de tela, y que simbolizan el maná que caía del cielo para que se alimentaran los israelitas durante su tránsito por el desierto tras el éxodo de Egipto ${ }^{61}$; como el sábado no podían recogerlo, para no incumplir el mandato del descanso sabático, el viernes caía en cantidad doble a la de los restantes días de la semana; y de ahí los dos panes que se colocan sobre la mesa. Tras la bendición del vino, tiene lugar la bendición y fracción del pan; pero para ello, quien preside la cena debe proceder a un lavado ritual de las manos. Este lavado de las manos recuerda que tras la destrucción del Templo de Jerusalén ya no hay altar para los sacrificios, considerándose la mesa como altar y la comida como sacrificio; simultáneamente al lavado de las manos se pronuncia la siguiente bendición ${ }^{62}$ :

«Bendito seas, Adonay, Dios nuestro, Rey del Universo, que nos santificaste con tus mandamientos y nos ordenaste lavar las manos".

Concluido el lavado de las manos se descubren los dos panes, y quien preside la cena toma un pequeño trozo de pan con la mano derecha (amosi), pronunciando la siguiente bendición:

\footnotetext{
${ }^{61}$ El maná es el alimento concedido por Dios a los israelitas durante la larga marcha que llevaron a cabo por el desierto, bajo la dirección de Moisés, tras su salida de Egipto. La etimología popular que da el texto del Éxodo relaciona el nombre de maná con la pregunta que se hicieron los israelitas cuando lo descubrieron por primera vez:

«Y habiendo cubierto la superficie de la tierra, se vio en el desierto una cosa menuda, y como machacada en mortero, a semejanza de escarcha sobre la tierra. Lo que habiendo visto los hijos de Israel, se dijeron el uno al otro: ¿Manhú?, que quiere decir: ¿Qué es esto?, porque no sabían lo que era. A los cuales dijo Moisés: Esto es el pan que el Señor os ha dado para comer» (Éxodo, XVI, 14-15).

62 Señal indiscutible de la importancia concedida al pan en el judaísmo es que este producto, como el vino, contaba con una bendición especial, distinta de la de los demás alimentos vegetales.
} 
«Bendito seas, Adonay, Dios nuestro, Rey del Universo, que sacas el pan de la tierra».

Seguidamente ingiere el amosí, fracciona el pan y lo distribuye a los restantes comensales, quienes pronuncian asimismo la bendición del pan. La cena del Shabat, que tiene lugar a continuación, se desarrolla en un ambiente marcadamente ritual y va acompañada de la entonación de himnos propios de este día, concluyendo con la recitación de la acción de gracias, que se hace, habitualmente, con una copa de vino.

El pan constituye también uno de los ingredientes fundamentales de la más importante comida ritual judía: el séder de Pésah, que tiene lugar la noche del primer día de luna llena del mes de nisán ${ }^{63}$, coincidente siempre con el día 15 de este mes. La fiesta de Pésah, que se celebra durante siete días en Israel y durante ocho días en la Diáspora, conmemora la salida de los israelitas de Egipto, que es narrada en el capítulo XII del libro del Éxodo.

La Pascua es una de las tres grandes fiestas de peregrinación a Jerusalén en el judaísmo primitivo. En sus orígenes era una fiesta de pastores nómadas, que los israelitas celebraban ya desde bastante tiempo antes de Moisés, y en la que ofrecían las primicias de sus rebaños, inmolando un cordero o un cabrito para asegurarse la prosperidad; luego, al sedentarizarse, esta fiesta se fusionó con otra de carácter agrícola, la de los ácimos, que los cananeos celebraban al comienzo de la siega del cereal de primavera, y cuyo rasgo característico más sobresaliente era la prohibición de consumir alimentos fermentados. Una y otra eran fiestas de peregrinación, y se celebraban en el primer plenilunio de primavera, por lo que su fusión no era difícil; así, tras los acontecimientos ocurridos en tiempos de Moisés, estas fiestas comenzaron a celebrarse como conmemoración de la salida de los israelitas de Egipto lo que, según la tradición, había tenido también lugar en primavera ${ }^{64}$.

La prohibición bíblica de consumir durante los siete días de la Pascua alimentos fermentados (hamez) y, en particular, pan con levadura ${ }^{65}$, obligaba a preparar en los días previos a la fiesta la cantidad necesaria de pan ácimo, o pan "cenceño» como lo conocían habitualmente los judíos hispanos. La elaboración del pan ácimo se hace en forma de tortas (matzot), en rememoración de las tortas que los hebreos sacaron de Egipto, y para ello se sigue la estricta reglamentación fijada por el Talmud (tratado Pesahim).

Para evitar la más mínima fermentación en los granos de cereal o en la harina que se utilizaría para la elaboración de las matzot, los judíos tomaban muchas precauciones, vigilando los granos para que no se mojaran y se enmohecieran en el

\footnotetext{
${ }^{63}$ Séptimo mes del calendario civil judío, y primero del litúrgico. Tiene treinta días, y su comienzo oscila entre el 13 de marzo y el 11 de abril. En él se celebra la festividad de Pésah, la más importante de las fiestas judías.

${ }^{64}$ Carlos del VALLE RODRÍGUEZ, El mundo judío. Madrid. Universidad Nacional de Educación a Distancia, 1976, pág. 126.

${ }^{65}$ Éxodo, XII, 17-20; Deuteronomio, XVI, 3-4.
} 
almacén y en el molino, lo que favorecería la fermentación, y controlando minuciosamente el proceso de amasado y cocción del pan, a fin de que no se produjera la fermentación de la masa; a este fin, la harina se amasaba normalmente con agua fría, por si el agua tibia pudiera favorecer la fermentación. Asimismo, y aunque la Ley no lo exige, solía evitarse el añadido de sal y de otros condimentos. Las matzot se confeccionaban, indistintamente, con harina de trigo, de cebada, de espelta, de avena o de centeno; no era inusual que se añadieran a la masa otros ingredientes como huevo, miel o jugos de frutas, excepto en las matzot que se consumían en el séder de la noche del primer día de la Pascua, ya que, como prescribe el Talmud, éstas deben ser lehem oni, es decir "pan de los pobres»"6. Las matzot de la primera noche debían prepararse unas horas antes de la celebración del séder, para rememorar la salida de los israelitas de Egipto cuando, debido a la precipitación de la salida, no pudieron dejar que las masas fermentaran. Por el contrario, las matzot de los restantes días de la Pascua se preparaban, normalmente, con algunos días de antelación. Además, las matzot del séder eran diferentes en su forma y tamaño a las que se consumían a diario durante los días de la Pascua.

Las tortas no debían ser de más de cuatro dedos o pulgadas de grosor ${ }^{67}$. Una vez que se daba a las matzot la forma deseada, se perforaba la pasta con un instrumento especial (seriquín), para evitar que subiera al cocerse en el horno. En la Edad Media era frecuente que esta perforación se hiciera con diseños artísticos que representaban animales o flores, aun cuando algunos rabinos se oponían a esta costumbre, porque con ella se prolongaba el proceso de elaboración de las matzot que, en ningún caso, debería sobrepasar el tiempo necesario para caminar dos mil codos, es decir unos 27 minutos.

Pese a su profundo simbolismo religioso ${ }^{68}$, no se otorga carácter sagrado a las matzot, por lo que nada impide que puedan ser ofrecidas para su consumo a gentiles. No obstante, en época medieval algunos judíos atribuían virtudes protectoras, como talismán, a los pequeños trozos de matzot conocidos como aficomán que se reservaban para el final del séder de Pésah al fraccionar el pan al comienzo de la cena.

La prohibición de consumir pan fermentado durante los siete días de la Pascua era tan rigurosa que el primer acto de limosna o de caridad (zedacá) para un judío consistía en ofrecer a los pobres la cantidad de harina necesaria para elaborar las matzot. El rigor en el cumplimiento de la prohibición de consumir alimentos fer-

66 Tratado Pesahim, 36a.

${ }^{67}$ En la actualidad no suelen sobrepasar el medio centímetro de espesor, y los 18 ó 20 centímetros de diámetro.

${ }^{68}$ Entre los judíos de la Europa oriental y del Próximo Oriente se mantuvo durante mucho tiempo la costumbre de colgar una matzá en la sinagoga para, de este modo, cumplir con el precepto del Deuteronomio (XVI, 3): «No comerás nada leudado. Durante siete días comerás pan ácimo, el pan de la pobreza, porque saliste de la tierra de Egipto apresuradamente, para que te acuerdes siempre del día en que saliste de la tierra de Egipto". 
mentados obligaba a los judíos a la observancia de diversos ritos. Así, antes del inicio de la Pascua, deben ser frotados concienzudamente y sumergidos en agua hirviendo todos los utensilios metálicos de cocina, con el fin de limpiarlos del más mínimo resto de levadura que pudieran aún tener; con el mismo fin, deben ser purificados en el baño ritual judío (micvé) todos los utensilios de vidrio y de cerámica que fueran a ser utilizados durante los días de Pascua. Por este motivo, no era infrecuente que las familias que gozaban de una posición económica más desahogada dispusieran de utensilios de cocina y de una vajilla especial para los días de Pascua. Del mismo modo, y en cumplimiento de lo preceptuado en el libro del Éxodo:

«Durante siete días no se hallará levadura en vuestras casas, porque el alma de quien comiere alimento leudado será extirpada de la congregación de Israel, tanto el forastero como el natural de la tierra» ${ }^{69}$,

la víspera de la Pascua los judíos procedían a una limpieza a fondo de la casa, que culminaba al anochecer del día 14 de nisán con el rito conocido como bedicat-hamez, que consistía en una revisión minuciosa, con la ayuda de una vela, de todos los rincones de la casa, con el fin de descubrir y retirar cualquier resto de levadura que pudiera quedar. Antes de iniciarse la búsqueda de los restos de hamez, se pronuncia la siguiente bendición:

«Bendito seas, Adonay, Dios nuestro, Rey del Universo, que nos consagró por medio de sus preceptos y nos encomendó eliminar el hamez".

Siguiendo las enseñanzas de los sabios del Talmud, todo el hamez que fuera hallado en la limpieza de la casa debería ser eliminado echándolo al fuego ${ }^{70}$. A este fin, se encendía una hoguera en el jardín, en el patio trasero de la vivienda o en la calle, que se conocía como «fuego de Pésah».

Pero el símbolo más representativo de la Pascua judía es el séder, es decir el banquete ritual que se celebra la primera noche de la fiesta de Pésah. Como en la cena del Shabat, la mesa se prepara con gran esmero antes de que anochezca y se cubre con el mejor mantel de que dispone la familia. Encima de la mesa se colocan los recipientes para las matzot (quearáh), que suelen consistir en una bandeja metálica o en un canasto; contienen tres matzot, que se cubren con tres paños de tela o con un solo paño plegado en tres partes ${ }^{71}$. Dos matzot ocupan el lugar de los dos panes que se consumen en la cena del shabat, y la tercera se fracciona en dos mitades: una mitad se emplea para la bendición ritual del pan, haciendo las veces del amosí, en tanto que la otra mitad se reserva para el final del séder (aficomán).

${ }^{69}$ Éxodo, XII, 19.

${ }^{70}$ Así dice Rabí Yehudah: «El único método para eliminar el hamez es quemándolo. Los sabios dicen: También es posible destrozarlo y desparramarlo al viento, o echarlo al mar» (Pesahim, 21a).

${ }^{71}$ Según Isaac Luria, un afamado cabalista italiano del siglo XVI, las tres matzot representan a los tres estamentos que conformaban el pueblo hebreo: los cohanim o sacerdotes, los levitas o funcionarios religiosos de categoría inferior a los sacerdotes, y los restantes miembros del pueblo de Israel. 
Una vez fraccionada la tercera matzá y reservado el aficomán, que permanece cubierto con un paño hasta el final de la cena, quien preside el séder eleva el recipiente que contiene las matzot y pronuncia las primeras palabras del relato de la hagadá de Pésah: "ha lahma» (= he aquí el pan), que señalan a los panes ácimos como el elemento principal de la fiesta. En época medieval estaba extendida entre los judíos ashkenazíes la costumbre de que todos los participantes en el séder se unieran al que lo preside para elevar conjuntamente el recipiente de las matzot, en tanto que entre los judíos hispanos era más frecuente que quien presidía el séder depositara el recipiente con las matzot sobre la cabeza de uno de los comensales, pasando luego sucesivamente sobre la cabeza de los restantes comensales, en recuerdo de la salida de los israelitas de Egipto cuando, debido a las prisas de la partida, cargaron sobre sus espaldas las artesas con la masa aún no fermentada ${ }^{72}$. Seguidamente, quien preside el séder fracciona y distribuye las dos matzot entre los comensales.

La Mishná ${ }^{73}$ señala que después del cordero no debe ingerirse nada más en el séder $r^{74}$, es decir que no debe tomarse postre. Sin embargo, después de la destrucción del Segundo Templo (70 d.C.) se extendió entre los judíos la costumbre de repartir a los comensales al final de la cena un pequeño trozo de matzá, el aficomán, término que para algunos autores deriva del griego epikomion (= postre). El Talmud señala al respecto lo siguiente:

«Dijo Rabí Yehudah en nombre de Samuel: Después de la matzá no se come ningún postre (refiriéndose a nuestra época que no sacrificamos el Pésaj —cordero pascual-); debemos comer un trozo de matzá al final de la cena, y el gusto de esa matzá debe quedar en la boca, por lo que está prohibido comer otro bocado, que quitaría tal gusto de la boca» ${ }^{75}$.

Es ésta una señal inequívoca del lugar preeminente que las matzot tienen en la celebración de Pésah y en el orden del séder.

\section{Significado religioso del vino en el Judaísmo}

Desde el punto de vista religioso, el vino no ocupaba un lugar destacado en el ceremonial de los sacrificios en el antiguo Israel ${ }^{76}$. Así, el vino no constituía una

72 Éxodo, XII, 34 y 39.

${ }^{73}$ Código legal rabínico, compilado en el siglo II d.C. Se divide en seis órdenes: Zeraim (= semillas), que trata de las leyes concernientes a la agricultura; Moed (= días festivos), que se refiere a las leyes del shabat y de los demás días festivos; Nashim (= mujeres), que describe las leyes del matrimonio, divorcio y votos; Nezikin (= daños), que trata de los delitos civiles y criminales; Kodashim (= cosas sagradas), que expone las leyes relativas al degüello ritual de los animales, a los sacrificios y a los objetos sagrados; y Teharot (= purezas), que se refiere a las leyes de pureza ceremonial.

74 Tratado Pesahim, X, 8.

75 Tratado Pesahim, 119b.

${ }^{76}$ El ceremonial del sacrificio consistía en el holocausto, es decir en la ofrenda total de la víctima que, tras la imposición de manos, el degollamiento y la aspersión con sangre, era completamente quemada sobre el altar, subiendo su humo al cielo. El código sacerdotal contiene disposiciones precisas acerca de los animales que podían sacrificarse en holocausto y sobre los ritos de éste (Levítico, I, 1-17). 
ofrenda propiamente dicha, sino tan sólo un elemento acompañante del animal que era sacrificado, derramándose en el altar de los holocaustos ${ }^{77}$. Por el contrario, el vino comenzó a tener un papel más relevante en la vida religiosa judía en los tiempos rabínicos, pasando a ocupar un lugar importante en el ritual de la sinagoga y, de forma muy particular, en las celebraciones religiosas de carácter familiar. De este modo, se concedió una significación muy especial al vino que acompañaba al cordero pascual en el séder o cena ritual de la Pascua, y todas las festividades judías, en particular el shabat, se inician con la bendición ritual del vino (quidús), que es, significativamente, el único producto frutícola que tiene una bendición pro$\mathrm{pia}^{78}$.

Aun cuando ya desde los tiempos bíblicos era habitual entre los judíos iniciar los banquetes con una copa de vino, fueron los rabinos quienes impusieron la costumbre de comenzar la festividad del Shabat con la bendición del vino al inicio de la cena del viernes. De este modo se daba también cumplimiento al mandato bíblico de recordar la festividad del shabat, día que los judíos deben proclamar y santificar ( «Te acordarás del día del reposo para santificarlo» ${ }^{79}$ ), pues la bendición del vino hace alusión a la celebración del shabat.

Con posterioridad, en tiempos del Segundo Templo de Jerusalén, se extendió en Babilonia la costumbre de la bendición del vino como rito sinagogal en el oficio vespertino del viernes, lo que para algunos autores podría tener una doble motivación: que el vino era en Babilonia un producto más escaso que en Israel y más difícil, por tanto, que las familias pudieran disponer de él para la cena del viernes; y que la sinagoga primitiva hacía las veces de centro de acogida para los viajeros, por lo que, al no poder cenar en familia, procedían a la bendición ritual del vino en la sinagoga. Esta tradición se mantuvo en las escuelas rabínicas babilónicas durante algún tiempo, pese a que la sinagoga no tuviera ya sino una función meramente religiosa y cultural.

Tanto en su modalidad doméstica como en la litúrgica, el quidús consiste en una bendición de Dios por haber ordenado la santificación del Shabat —o del día festivo de que se trate en concreto-, así como por haber creado el fruto de la vid. A este fin, se recitan los versículos 1 a 3 del capítulo II del libro del Génesis, en los que se narra la bendición y santificación del sábado por parte de Dios:

"Y fueron acabados el cielo y la tierra y todas sus huestes. $Y$ habiendo terminado Dios el día séptimo la obra que había hecho, descansó el día séptimo de

77 La Torá establece que el sacrificio de un cordero debe ir acompañado de la libación de 1/4 de hin de vino (Éxodo, XXIX, 40-41; Números, XV, 5, y XXVIII, 7-9 y 14), el sacrificio de un carnero de la libación de 1/3 de hin de vino (Números, XV, 7, y XXVIII, 14), y el sacrificio de un becerro de la libación de 1/2 de hin de vino (Números, XV, 10, y XXVIII, 7).

El hin es una medida de capacidad del antiguo Israel utilizada para líquidos, semejante al jomer y equivalente a la sexagésima parte del coro, es decir a unos 393,93 litros.

${ }^{78} \mathrm{La}$ bendición del vino se contiene en el tratado Berakot (VI, 1), que pertenece al Primer Orden de la Mishná.

${ }^{79}$ Éxodo, XX, 8. 
todo el trabajo realizado. $Y$ bendijo Dios el séptimo día y lo santificó, porque en él descansó de toda la obra que había creado» ${ }^{80}$.

Los sabios del Talmud otorgan mucha importancia a la recitación de estos versículos, ya que recuerdan que Dios es el Creador y Señor del universo, y que entrega al hombre su obra a fin de que él la continúe. Así, el tratado Shabat del Talmud dice lo siguiente:

«Aquel que pronuncia esta oración el viernes al anochecer es considerado por las Sagradas Escrituras como si se asociara al Santo, bendito sea, en la tarea de la Creación» ${ }^{81}$.

Acabada la recitación de los versículos del Génesis se procede a la bendición del vino, para lo que, mientras se sostiene la copa con la mano, se pronuncia la siguiente oración:

«Bendito seas, Adonay, Dios nuestro, Rey del Universo, Creador del fruto de la vid. Bendito seas, Adonay, Dios nuestro, Rey del Universo, que nos santificaste con tus mandamientos, te complaciste en nosotros y con amor y agrado nos has legado el santo sábado en memoria de la obra de la Creación, pues éste es el primero de los días de la santa convocación, en recuerdo del éxodo de Egipto; y tu sábado santo nos lo has legado con amor y agrado. Bendito seas Tú, Eterno, santificador del Shabat".

Al concluir la fórmula de la bendición, quien la pronuncia bebe un poco de vino y pasa la copa a los restantes comensales, quienes beben asimismo un sorbo. En las comidas familiares quien pronuncia la bendición es, normalmente, el cabeza de familia.

Muy expresiva de la bendición del vino en la festividad del Shabat es la testificación que el día 3 de octubre de 1483 hizo ante el tribunal de la Inquisición de Ciudad Real Juan González, tejedor vecino de Santa María de Los Dos Hornos (Ciudad Real), en el proceso que se siguió en los años 1483-1485 contra Diego de la Sierra, judeoconverso vecino de Ciudad Real, y que conocemos a través del proceso promovido contra su hermano Juan de la Sierra en los años 1515 a 1527. Juan González declaró que conocía a Alonso González de Frexinal, padre de Diego de la Sierra, ya difunto, desde hacía más de veintisiete años, y que haría unos quince años, un sábado que entró en su casa para reclamarle unos dineros que le debía,

«vido cómo el dicho Alonso González, después que obo comido, tomó un vaso con vino con amas manos y començó de rezar y sabadear sobre él, y començólo de levantar sobre la cabeça como cáliz quando alzaba, y tornolo luego a abaxar, y tornó a rezar y sabadear sobre él; su mujer e sus hijos estavan todos presentes en derredor de la mesa, bevió él un poco e dio a su mujer e a sus hijos,

\footnotetext{
80 Génesis, II, 1-3.

${ }^{81}$ Shabat, 119 b.
} 
e después desto besáronle la mano sus fijos e asimismo a su madre, y él púsoles la mano sobre la cabeça. Este testigo vido todo esto estando tras unas tinajas donde no le veýan»82.

La pronunciación del quidús debe hacerse con la copa llena de vino, y sin que nadie lo haya probado con anterioridad, ya que en este caso se consideraría que se trataba de un resto, por lo que no sería apropiado para la bendición ${ }^{83}$; tampoco se debe comer ni beber antes de pronunciar el quidús. Aunque la Ley judía no establece ninguna prescripción al respecto, algunos rabinos de época medieval aconsejaban que para la bendición del vino se utilizara vino tinto ${ }^{84}$. La copa del quidús debe estar perfectamente limpia, y no debe tener ningún defecto, siendo habitual en época medieval que todas las familias judías, incluso las que disponían de menos recursos económicos, tuvieran en su casa una copa especial para el quidús del Shabat, más o menos bellamente labrada.

Pese a que las mujeres no están obligadas en el judaísmo al cumplimiento de obligaciones religiosas positivas (miswot), es decir aquellas que deben ser realizadas en un momento determinado, ni siquiera a participar en la oración comunitaria en la sinagoga, por el contrario sí deben pronunciar el quidús, lo que da idea de la importancia de este precepto sabático.

La festividad del Shabat concluye poco antes de la puesta del sol del sábado con el rito denominado havdalá (= separación, distinción), que simboliza la separación entre el día sagrado y un día normal. Esta ceremonia consiste, básicamente, en la recitación de cuatro bendiciones: una, nuevamente, sobre una copa de vino; otra sobre unas hierbas aromáticas (generalmente, unos granos de incienso o alguna especia aromática) guardadas en una caja más o menos lujosamente decorada; otra sobre una vela encendida; y la última, la de la havdalá propiamente dicha, que simboliza la separación entre lo sagrado y lo profano.

La bendición del vino ocupa también un lugar especialmente importante en el séder de Pesah, es decir la cena ritual con la que se da comienzo a la fiesta de la Pascua judía, y a la que se ha hecho ya referencia con anterioridad. Al igual que en la festividad del shabat, el séder de Pesah se inicia con la pronunciación del quidús sobre una copa de vino. Más tarde, y a lo largo del séder, todo judío - varón o mujer-, debe beber de forma ritual cuatro copas de vino ${ }^{85}$. El Talmud de Jerusalén explica esta prescripción de la siguiente manera:

\footnotetext{
${ }^{82}$ Archivo Histórico Nacional (en adelante A.H.N.), Inquisición, leg. 184, n 11. Haim BEINART, $R e-$ cords of the Trials of the Spanish Inquisition in Ciudad Real. Jerusalem. Israel National Academy of Sciences and Humanities, 1974-1985, 4 vols. (en concreto, vol. III, págs. 568-569).

${ }^{83}$ Así se establece en la Mishná, Segundo Orden, Tratado Pesahim, 105 b.

${ }^{84}$ Este es el caso, por ejemplo, del célebre cabalista catalán Rabí Moshé ben Nahmán, más conocido como Nahmánides (1194 - c. 1270).

${ }^{85}$ Las cuatro copas de vino se beben en momentos concretos a lo largo del séder. la primera, tras la pronunciación del quidús, es decir al comienzo de la cena; la segunda, al concluir la primera parte de la cena, o Rojtzá; la tercera, después de la acción de gracias, o Barej; y la cuarta, al concluir la segunda parte del Hallel, o lectura de los Salmos 113 a 118, que pone fin al séder.
} 
"Las cuatro copas de vino, ¿de dónde las deducimos? Rabi Yohanán dijo: ‘De los cuatro términos de redención: $Y$ os sacaré de debajo de las cargas egipcias, y os liberaré de la servidumbre de ellos, y os redimiré con brazo extendido, y os tomaré por pueblo mío» ${ }^{86}$.

Debido a que el libro del Éxodo contiene una quinta afirmación de redención para los israelitas ${ }^{87}$, era costumbre llenar también una copa, dedicada al profeta Elías, que permanecía llena a lo largo del séder, sin que nadie bebiera de ella.

Tanto en el Israel antiguo como en las comunidades judías de época medieval, las cuatro copas de vino se bebían acompañadas de una determinada actitud gestual: la copa se coge con la mano derecha, mientras el codo izquierdo se mantiene apoyado sobre la mesa o sobre un cojín, como símbolo de la liberación recobrada por el pueblo de Israel tras la salida de Egipto, ya que ésta era la postura en la que comían los hombres libres en el mundo greco-romano.

El quidús o bendición del vino se pronuncia también con ocasión de la celebración de otras diversas ceremonias judías. Así, al concluir la ceremonia de la circuncisión, el mohel que la ha practicado pronuncia la bendición ritual del vino sobre una copa que sostiene con la mano, dando seguidamente de beber de ella a los asistentes.

Del mismo modo, la bendición del vino ocupa también un destacado lugar en la ceremonia de la boda judía. Con los novios colocados debajo de la hupá ${ }^{88}$, el rabino que oficia recita las «siete bendiciones del matrimonio» (shevá berakot) con una copa de vino en la mano, de la que seguidamente da de beber a los contrayentes, como símbolo de que en adelante habrán de compartir todos los bienes. Para concluir, el novio coloca un anillo de compromiso en el dedo de la novia, como señal de que la toma por esposa. Tras el banquete nupcial, se recitan nuevamente las siete bendiciones, que se pronuncian también en las comidas de los siete días siguientes a la boda; estas bendiciones se pronuncian con una copa de vino en la mano, de la que seguidamente beben los nuevos esposos.

Por último, en la celebración doméstica de la festividad de Rosh ha-Shaná, o Año Nuevo judío ${ }^{89}$, ocupa un lugar destacado el quidús que el cabeza de familia

${ }^{86}$ Talmud de Jerusalén, Segundo Orden, Tratado Pesahim, X, 1.

En efecto, los versículos 6 y 7 del capítulo VI del libro del Éxodo dicen lo siguiente: «Por lo tanto diles a los hijos de Israel: 'Yo soy el Eterno y os libraré de los trabajos forzados en Egipto y os salvaré de la servidumbre con brazo extendido y con grandes castigos (a los culpables). $Y$ os consideraré pueblo mío y seré vuestro Dios, y sabréis que Yo soy el Eterno, vuestro Dios, al redimiros de los trabajos forzados en Egipto".

87 «Y os llevaré a la tierra que juré dar a Abraham, a Isaac y a Jacob, y os la daré por heredad. Yo el Eterno" (Éxodo, VI, 8).

${ }^{88}$ Así se denomina al dosel o palio nupcial que simboliza el techo común que los novios van a compartir y la protección divina que van a recibir. Entre los judíos españoles era muy frecuente que la hupá consistiera, sencillamente, en un manto de oración (tallit) sostenido sobre la cabeza de los novios por cuatro parientes.

${ }^{89}$ Esta fiesta se celebra los días 1 y 2 del mes de tishri, coincidiendo con la neomenia del mes de septiembre, y en ella se conmemora la creación del mundo y el sacrificio de Isaac. El rito más caracte- 
pronuncia en la comida del segundo día de la fiesta, con los frutos de la cosecha sobre la mesa, de forma que se proclama de forma simbólica el poder creador de Dios.

\section{EL PAN Y EL VINO EN EL JUDAÍSMO MEDIEVAL}

A lo largo de la Edad Media, el pan y el vino siguieron ocupando un lugar especialmente importante en la dieta alimenticia de los judíos en las más diversas áreas de la Europa occidental y central, tanto en el ámbito geográfico del judaísmo sefardí como en el del ashkenazí. Y la misma relevancia se observa en lo que respecta a los aspectos más propiamente religiosos.

\section{El pan en la alimentación cotidiana y en la religión judías en la Edad Media}

Los cereales constituían la base por excelencia de la alimentación del hombre europeo en la Edad Media, lo que incluye también al mundo judío. Los principales cereales panificables eran el trigo, el centeno y la avena, que se consumían en forma de pan, como sémola o como gachas ${ }^{90}$. El consumo de cereal era muy elevado entre las familias con recursos económicos más limitados, lo mismo entre los cristianos que entre los judíos, de forma que la ración media de cereal se calcula en un kilo y medio por persona y día. Y su importancia en la dieta alimenticia era tal que en época de carestía de alimentos suplía las proteínas aportadas normalmente por la carne o el pescado.

Ninguna diferencia existía entre el pan consumido por cristianos y judíos, excepto durante los siete días de la Pascua, en los que los judíos tienen terminantemente prohibido el consumo de pan con levadura. Así, los judíos y los judeoconversos hispanos de época medieval distinguían entre el "pan lindo", que era como solían denominar al pan que consumían a diario, y el «pan cenceño» o pan ácimo, es decir el pan sin levadura, que era el que consumían durante la Pascua en forma de matzot o tortas circulares de escaso grosor. Sin embargo, existían peculiaridades y costumbres que afectaban al proceso de elaboración del pan por los judíos, y que, en ocasiones, provocaban situaciones de conflictividad con las autoridades públicas y, en particular, con la población mayoritaria cristiana.

Una costumbre judía medieval relacionada con el proceso de elaboración del pan consistía en que, cuando se amasaba el pan, se cogía un pellizco de la masa y se echaba al fuego. Este rito, cuyo cumplimiento doméstico recaía en las muje-

\footnotetext{
rístico consiste en hacer sonar durante la oración de la mañana el shofar, es decir una especie de trompeta hecha con un cuerno de carnero vaciado. La fiesta está marcada por el espíritu de arrepentimiento y de buenos propósitos para el año que se inicia, y da comienzo a diez días de penitencia que culminan en la fiesta de Yom Kipur.

${ }^{90}$ Masa a base de harina cocida con agua y sal, a la que podía añadirse leche, miel u otro aderezo.
} 
res, ya que eran ellas las que habitualmente preparaban la masa en sus casas, tiene su origen en el mandato bíblico que prescribe que las primicias de todas las harinas debían entregarse en el Templo, como ofrenda a Dios y para el mantenimiento de los sacerdotes:

"Y le dijo el Eterno a Moisés: Diles a los hijos de Israel: 'Cuando hubiereis entrado a la tierra adonde os llevo y comáis su pan, brindaréis de él ofrenda al Eterno. Como primicia ofreceréis una torta de vuestra primera horneada de harina, por ofrenda alzada, del mismo modo que ofrecéis las primicias de vuestro granero. En todas vuestras generaciones será para el Eterno la primera masa, por ofrenda alzada'»91.

"Y le dijo el Eterno a Moisés: Diles a los hijos de Israel: 'Cuando lleguéis a la tierra que os prometí daros recogeréis la cosecha y traeréis un ómero2 de los primeros frutos al sacerdote. Y él alzará, balanceándola, esa ofrenda ante el Eterno, para que sea aceptada. Lo hará a la mañana siguiente del día de descanso. Y ofreceréis ese día un cordero sin tacha de un año por holocausto al Eterno. Y su ofrenda vegetal será de dos diezmos de harina de sémola amasada con aceite. Será ofrenda ígnea de olor grato al Eterno, y su libación de vino será de un cuarto de hin. Y no comeréis pan leudado ni grano tostado ni espigas frescas hasta el día de la ofrenda a vuestro Dios. Será ley perpetua para vuestra posteridad en todas vuestras moradas.

Y contaréis siete semanas completas desde el día posterior al primer día de Pascua, o sea desde el día que trajisteis el ómer de la ofrenda alzada. Al cumplirse cincuenta días, o sea al día siguiente del plazo de siete semanas, ofreceréis una nueva oblación al Eterno. Para ello sacaréis de vuestra morada dos panes para ofrenda alzada en balanceo, cocidos con dos diezmos de harina de sémola con levadura. Serán primicias para el Eterno. Y ofreceréis además del pan siete corderos sin mácula, de un año, y un novillo y dos carneros, que serán holocausto para el Eterno, con la ofrenda vegetal y la libación. Será ofrenda ígnea de olor grato al Eterno. Y luego sacrificaréis un macho cabrío por expiación y dos corderos de un año por sacrificio pacífico. Y el sacerdote los alzará, meciéndolos, sobre el pan de las primicias, como ofrenda alzada ante el Eterno; y los panes, junto con los dos corderos consagrados al Eterno, serán para los sacerdotes" ${ }^{93}$.

Tras la destrucción del Templo de Jerusalén en el año 70 d.C., los rabinos prescribieron el rito de la hallá en recuerdo de la antigua ofrenda de las primicias de las harinas, y se esforzaron porque se extendiera a la diáspora ${ }^{94}$. Con cierta frecuencia se hace referencia a este rito en los procesos inquisitoriales promovidos a fines del siglo $\mathrm{XV}$ y en los primeros decenios del siglo XVI contra judeoconversos

\footnotetext{
91 Números, XV, 17-21.

92 Medida de capacidad del antiguo Israel para materias sólidas, y que es citada en diversas ocasiones en la Torá, principalmente en relación con el maná. Medía un décimo de efá y un centésimo de jomer, lo que equivale a unos 3,64 litros.

93 Levítico, XXIII, 9-20.

${ }_{94}^{4}$ Mishná, Primer Orden: Zera'im (Siembras), tratado Hallá, relativo a la ofrenda de la masa de pan.
} 
españoles acusados de judaizar, como signo inequívoco de la práctica secreta de ritos de la religión judía. De este modo, en un manual para inquisidores del siglo $\mathrm{XVI}$, que se conserva en el Archivo Histórico Nacional de Madrid ${ }^{95}$, y en el que se hace una pormenorizada referencia a las principales creencias y ritos de la religión judía, ofreciendo asimismo noticias sumamente interesantes acerca de costumbres y prácticas de los judíos y judeoconversos españoles, se dice lo siguiente en relación con el rito de la hallá:

«Iten tenían otra çerimonia que hera sacar un poco de masa las mugeres de la masa que tenían amasada e echarla en el fuego, a la qual llamavan hallá. La rrazón hera por un mandamiento que les dio Moysén, en que deçía en su lengua: 'Resit ari cole quim ti tenu la cohen', que en rromançe quiere deçir: 'La primiçia de vuestras masas daréis al saçerdote', Levítici, capítulo (en blanco) ${ }^{96}$. E porque en este tiempo no avía sazerdote, hechábanla en el fuego. En rromançe hallá quiere deçir torta» ${ }^{97}$.

Mucho más compleja, y generadora de conflictos, era la disposición talmúdica que prohibía a los judíos el consumo de alimentos cocidos por gentiles. Esta prescripción tiene sus orígenes en la Antigüedad tardía, y tenía como finalidad impedir las relaciones de convivencia entre judíos y gentiles, en particular en regiones en las que había una importante presencia de zoroastrianos (Irán). Más tarde, la prohibición para los judíos de consumir pan cocido por cristianos podía dar lugar en la Edad Media a conflictos de cierta importancia, si tenemos en cuenta que en numerosas localidades los vecinos, cristianos y judíos, estaban obligados a llevar a cocer el pan al horno del rey o del señor ${ }^{98}$.

Con el fin de solucionar esta compleja cuestión, los rabinos europeos de época medieval determinaron que era admisible la cocción realizada por un cristiano cuando en ella intervenía un judío, aunque fuera de forma meramente simbólica como, por ejemplo, arrojando un leño al fuego. Esta solución que, entre otros autores judíos de época medieval, es apuntada por Maimónides en su Mishné Torá99, se sustenta en un principio similar admitido por los rabinos de Babilonia en los primeros tiempos de la Edad Media, aunque no por los de Palestina; no hay que perder de vista que las condiciones de vida eran considerablemente más difíciles para

${ }^{95}$ Archivo Histórico Nacional, Inquisición, libro 1254, fols. 153-172.

${ }^{96}$ En el capítulo II del Levítico se refieren las ceremonias relativas a las ofrendas de los panes de la flor de harina y de las primicias.

${ }^{97}$ Archivo Histórico Nacional, Inquisición, libro 1254, fol. 171. Enrique CANTERA MONTENEGRO, Aspectos de la vida cotidiana de los judíos en la España medieval. Madrid. Universidad Nacional de Educación a Distancia, 1998, pág. 232.

${ }_{98}$ Es muy interesante a este respecto el estudio de Joseph SHATZMILLER, «Droit féodal et législation rabbinique: la cuisson du pain chez les juifs du Moyen Âge », en Manger et boire. Actes du Colloque de Nice (15-17 octobre, 1982). Nice. Centre d'Études Médiévales de Nice, Publications de la Faculté des Lettres et Sciences Humaines de Nice, 1984, 2 vols. (véase vol. 1. Aliments et Société, págs. 67-74).

${ }^{99}$ Importante código legal redactado por Maimónides en los años setenta del siglo XIl. Está formado por catorce libros, en los que regula de forma minuciosa cómo debe actuar un judío ante muy diversas circunstancias de la vida cotidiana. 
los judíos babilonios que para los palestinenses, y de ahí probablemente la mayor permisividad de los gaones de Babilonia.

Como señala Joseph Shatzmiller, las referencias documentales a la práctica de arrojar un leño al horno en el que se cocía el pan son bastante frecuentes en responsa ${ }^{100}$ y tratados de rabinos occidentales de los siglos XIII y XIV. A comienzos del siglo XIII, en sus responsa tituladas Teshuvot Al-Pi Halom, el rabino Jacob de Marvège afirmaba que el leño de madera debía ser arrojado al fuego por un judío cuando aún ardían brasas, y no cuando éstas estuvieran ya apagadas, ya que el leño habría de inflamarse de forma inmediata. Para Yehiel ben Yosef de París ${ }^{101}$ no era necesario que el ritual de arrojar un leño en el horno se cumpliera cada día y cada vez que se cocía pan, sino que sería suficiente con hacerlo una vez a la semana; es evidente el propósito de este rabino francés de flexibilizar las exigencias de la Ley, en la misma línea que otros importantes rabinos del momento. Unas centurias después el rabino Eliyahu Capsali (1483-1555) ${ }^{102}$, quien residió en Italia y en la isla cretense de Hyraction, señala que el consumo de pan cocido por gentiles está prohibido a los judíos, salvo que un judío arrojara un leño de madera al horno durante la cocción; y recuerda cómo en el tiempo en que realizó estudios en Italia, su maestro, Isaac Ashkenazi Segal, frecuentaba los jueves o los viernes de todas las semanas los hornos de los gentiles en los que los judíos cocían su pan, con el fin de arrojar un trozo de madera al horno encendido. Asimismo indica que los rabinos ashkenazíes cumplían minuciosamente con este ritual, hasta el punto de que las comunidades hebreas designaban a una persona para que se ocupara de esta tarea, recibiendo a cambio una compensación económica.

Por el contrario, otros rabinos mantenían opiniones menos permisivas. Es este el caso del rabino francés Moshé ben Yacob de Coucy, quien a mediados del siglo XIII defendía el criterio de que sólo sería aceptable el ritual de arrojar un leño al horno en aquellas localidades en las que los judíos no dispusieran de un horno propio. Y no menos interesante es la postura de Yonáh ben Abraham Girondí ( $c^{a}$

100 Son las respuestas que a principios de la Edad Media daban los rabinos de las escuelas superiores de Babilonia y de Palestina a las preguntas (She'elot u teshubot) que les eran formuladas desde los más diversos rincones de la diáspora judía. Posteriormente, esta función se extendió a las más reputadas autoridades halákicas del mundo judío, incluida la Diáspora.

${ }^{101}$ Afamado rabino francés, fallecido alrededor del año 1265, y gran conocedor del Talmud y de la Tosefta. En la disputa religiosa que se celebró en París en tiempos del rey Luis IX, defendió la posición judía frente al converso Nicolás Donin. En 1260 emigró a Acre con un numeroso grupo de discípulos, ejerciendo como director de una yeshibá, o academia para la formación bíblica y talmúdica; Acre, por aquel tiempo bajo dominio cruzado, se convirtió entonces en uno de los más influyentes centros de estudio del judaísmo.

102 Su crónica titulada Seder Eliyahu Zutá es importante para la historia de los judíos en el Imperio otomano y para la historia de los judíos expulsados de los reinos hispanos; se estructura en cinco libros, cada uno de ellos referido a distintos países e historias. Los capítulos 40 a 70 del segundo libro, en los que se narran los acontecimientos históricos relativos a Sefarad, cuentan con una excelente edición española a cargo de Yolanda MORENO KOCH, El Judaísmo hispano según la crónica hebrea de Rabí Eliyahu Capsali. Traducción y estudio del Séder Eliyahu Zutá (capítulos 40-70). Universidad de Granada, 2005. 
1200-1263 $)^{103}$, quien consideraba válido el ritual del leño para la cocción del pan, pero no para la cocción de otros alimentos, lo que se justifica por el hecho de que el pan era un producto imprescindible en la alimentación cotidiana. Por su parte, Yonáh Gerondí manifiesta su preocupación por la interpretación que de este ritual podrían hacer los no judíos, por lo que recomienda a las mujeres hebreas que expliquen a los horneros cristianos su significado real; asimismo sugiere que en cada comunidad judía se designe a una persona encargada de cumplir el ritual en nombre de todos los judíos, con el fin no sólo de simplificar el procedimiento sino, principalmente, de institucionalizarlo y de garantizar su cumplimiento.

Todo parece indicar que, en general, este ritual tuvo menor aceptación entre los judíos sefardíes que entre los ashkenazíes, de forma que los rabinos de las comunidades hispanas y magrebíes rechazaban su validez, considerando que el hecho de que un judío arrojara un trozo de madera al horno no cambiaba para nada la realidad de que el pan era cocido por gentiles. El rabino Menahem ben Aharon ben Zerah (1310-1385) 104 ponía en duda la validez del ritual de arrojar un leño al horno encendido, si bien no se muestra excesivamente intransigente con quienes lo practicaban, pues consideraba que, aunque erraban, lo hacían con buena fe.

Como señala Joseph Shatzmiller, lo realmente significativo es que el judaísmo ashkenazí que, en general, era de inspiración palestinense en todas aquellas cuestiones que concernían a la tradición y a la ley rabínica, en este caso concreto seguía el criterio del judaísmo babilónico. Y lo contrario cabe decir del judaísmo sefardí, más apegado a la tradición babilónica, y que en esta cuestión se alineaba con las tesis de los rabinos palestinenses. En cualquier caso, se trata de una más de las muchas divergencias existentes entre el judaísmo ashkenazí y el sefardí, cuyo auténtico fundamento habría que buscarlo, como en otros múltiples aspectos relativos a la ley rabínica en época medieval, en el ambiente social concreto y determinado en el que se desenvolvía la vida de los judíos. Así, Joseph Shatzmiller considera que los judíos ashkenazíes, sometidos a unas estructuras feudales más rígidas que las que caracterizaban a la sociedad de los países en los que residían los judíos sefardíes, se habrían visto necesitados de adoptar la solución babilónica para, cumpliendo con la obligación de llevar a cocer el pan al horno del señor, ser respetuosos con la Ley judía. Por el contrario, en los reinos hispánicos y en el Magreb, donde los judíos gozaban, tradicionalmente, de mayores libertades que en los países de la Europa central, los rabinos se mostraron bastante intransigentes en cuanto a la cocción del pan, en línea con la tradición palestinense ${ }^{105}$.

${ }^{103}$ Perteneciente al círculo de cabalistas de Gerona, estudió en Francia con el conocido talmudista Shelomo ben Abraham de Montpellier. Fue halakista, talmudista y moralista, y mantuvo una postura contraria a Maimónides y al racionalismo. Fue uno de los principales impulsores de un movimiento de reforma ético-social, que trataba de poner límites a los abusos contra la Ley hebrea por parte de los judíos hispanos. Murió en la ciudad de Toledo, en la que pasó los últimos años de su vida.

${ }^{104}$ Natural de la localidad navarra de Estella, estudió y residió en Toledo, así como en Alcalá de Henares.

105 Joseph SHATZMILLER, «Droit féodal et législation rabbinique : la cuisson du pain chez les juifs du Moyen Âge », pág. 70. 
Lo cierto es que el cumplimiento del ritual consistente en arrojar unos leños al horno producía, en ocasiones, conflictos de gravedad en las relaciones entre cristianos y judíos, que hay que situar en el clima de hostilidad y sospecha hacia todo lo judío que se extendió por toda la Europa occidental y central en la Baja Edad Media. Un buen ejemplo de uno de estos conflictos es el que acaeció en la localidad provenzal de Manosque, en el año 1313, y que ha estudiado Joseph Shatzmiller $^{106}$. El 3 de octubre de 1313 se instruyó un procedimiento contra el judío Haquinus Callot, a quien se acusó de pretender envenenar a los cristianos de Manosque arrojando objetos emponzoñados a los hornos de la ciudad, con el fin de intoxicar el pan que se cocía en ellos; Haquinus había sido denunciado por dos vecinos, quienes le habían visto merodear alrededor de varios hornos de la ciudad. El judío fue conducido inmediatamente a presencia del juez, ante quien confesó que, efectivamente, había arrojado unos trozos de madera a los hornos, asegurando que dicha acción era conforme a la religión judía, y que ningún propósito tenía de envenenar a la población cristiana. A la vista de las declaraciones de Haquinus y del rabino Isaac Cohen de Tulardo, quien también fue convocado ante el tribunal, el acusado quedó libre y se cerró la instrucción que se había abierto contra él. Es muy probable que Haquinus fuera un oficial de la aljama encargado de garantizar la pureza de los hornos en los que los judíos cocían su pan.

Pese a que son muy escasas las referencias documentales al cumplimiento de este ritual entre los judíos hispanos, lo cierto es que, fuera por motivación religiosa o económica, no eran infrecuentes los intentos de los judíos por eludir la obligación de llevar a cocer el pan a los hornos que gozaban del derecho de monopolio. Así, en 1282 el rey Pedro III de Aragón recordaba al batlle de Barcelona que los judíos estaban obligados a llevar a cocer su pan al horno de la viuda de Guillem Gruny, quien gozaba del derecho exclusivo ${ }^{107}$. En ocasiones, los judíos obtenían privilegios relativos a la cocción del pan: en 1290, al asignar un call o barrio apartado a los judíos de Mallorca, el rey Alfonso III de Aragón les concedía el derecho a poseer un horno propio y exclusivo, salvando los derechos de hornaje ${ }^{108}$; en 1390, el judío barcelonés Vidal Brunet recibió de la reina doña Violante autorización para cocer el pan en el horno que quisiera ${ }^{109}$. Del mismo modo, en algunas localidades de jurisdicción señorial los judíos compraban el derecho a cocer su pan en el horno de su elección; este es el caso de los judíos de la localidad toledana de Ocaña, quienes, en el último cuarto del siglo XV, recibieron tal privilegio a cambio del pago de 1750 maravedíes anuales a la Orden de Santiago, que gozaba del privilegio de monopolio sobre los hornos públicos de la villa.

Pero el problema más grave en relación con la cocción del pan se planteaba para los judíos con ocasión de la fiesta de Pésah, porque durante los siete días de

106 Idem, págs. 67-74.

107 Jaume RIERA I SANS, «La conflictivitat de l'alimentació dels jueus medievals (segles XII-XV) 》, en Alimentació i societat a la Catalunya medieval. Barcelona. C.S.I.C., Institució Milà i Fontanals, 1988, págs. 295-311 (véase pág. 303).

108 Ibídem.

109 Ibídem. 
esta fiesta los judíos no podían llevar a cocer el pan ácimo al horno común, ya que se convertiría en impuro por el simple contacto con los restos de levadura que pudieran quedar en el horno. Por lo tanto, no había otro remedio que cocer el pan en la propia casa, lo que durante los restantes días del año tenían normalmente prohibido, o cocerlo en hornos provisionales que se levantaban en el recinto de las juderías. Así, en abril de 1269 el rey Jaime I de Aragón concedía un privilegio a los judíos de Besalú para que pudieran cocer en sus casas el pan para el consumo familiar, desde dos días antes de la Pascua judía hasta el fin de la Pascua cristiana, sin tener que satisfacer por ello los derechos derivados del monopolio regio del horno de la villa ${ }^{110}$.

Entre los tipos de pan que consumen los judíos ya se ha hecho amplia referencia a las matzot, es decir las tortas de pan ácimo que se preparan con motivo de la Pascua, y que era en época medieval, y sigue siéndolo en la actualidad, el más conocido de todos los panes elaborados por los judíos.

Entre los sefardíes del Próximo Oriente, el pan del shabat y de los días festivos es también, habitualmente, un pan especial, que recibe el nombre de jalé o jalá o de barjes ${ }^{111}$. Se trata de un pan elaborado con harina blanca, en forma de trenza, y que con frecuencia se unta con yema de huevo a fin de que adquiera una tonalidad dorada y brillante, y se espolvorea con comino o con sésamo. Su textura resulta esponjosa, como si fuera bizcocho.

Otro tipo de pan especial es el llamado «pan de los siete cielos», que se elabora para la fiesta de Shavuot ${ }^{112}$. Es un pan formado por siete círculos, que representan los siete espacios que separan la tierra y el cielo, y por un montículo de masa en el centro, que representa al monte Sinaí, donde Dios entregó las Tablas de la Ley a Moisés. Sobre los círculos se representan con masa de pan cinco figuras alusivas a la fiesta que se celebra: las Tablas de la Ley; una mano, símbolo de la buena suerte, y cuyos cinco dedos representan los cinco libros de la Torá; un pez, símbolo también de la buena suerte y del Mesías; una paloma, símbolo de paz y de la ascensión del alma a los cielos; y una escalera, la escalera de Jacob, que simboliza la estrecha conexión entre el mundo terrenal y los siete cielos.

Pero, además del pan, en la cocina hispanojudía y sefardí ocupaban también un destacado lugar, ya en época medieval, las empanadas y empanadillas, que en algunos manuscritos rabínicos españoles recibían el nombre de pashtida, término

110 Ibídem.

${ }^{111}$ El origen hispano de este tipo de pan queda de manifiesto en el nombre coloquial que recibe entre los judíos del Próximo Oriente, quienes lo conocen como «pan de España» o «bizcochuelo español».

112 Es una de las tres festividades mayores del calendario litúrgico judío. Se celebra el día 6 del mes de siván, a las siete semanas o en el día quincuagésimo (= Pentecostés) después de Pésah. En sus orígenes era una festividad agrícola, la fiesta de las primicias, pero tras la destrucción del Segundo Templo de Jerusalén (70 d.C.) se transformó en una fiesta histórica que actualiza la revelación de la Ley en el monte Sinaí. Es un día muy alegre, en el que es frecuente que las casas de los judíos se adornen con flores y con otros diversos ornamentos. 
también empleado en el Talmud de Babilonia para referirse a un plato propio del shabat. Porque la empanada era en la Edad Media, y sigue siendo en la actualidad, un plato típico del shabat, lo que para algunos autores pudiera obedecer a que el relleno entre dos capas de masa simbolizaría la doble ración de maná que durante el peregrinaje de los judíos por el desierto caía en las tardes de los viernes. Las empanadas podían ser saladas o dulces, por lo que hacían las veces de plato principal o de postre ${ }^{113}$. En su versión salada, las empanadas se rellenaban, normalmente, con carne, y con menos frecuencia con pescado, con queso o con verduras, principalmente con berenjenas o espinacas. En su versión dulce, se rellenaban con cabello de ángel o con nueces. También eran frecuentes entre los judíos españoles unas empanadas pequeñas o empanadillas, que los sefardíes del Próximo Oriente denominan, por influencia turca, «borecas». La masa de estas empanadillas se elaboraba a base de harina, aceite, agua y sal, rellenándose con carne, pescado, queso o verduras.

Por último, en la repostería sefardí la harina ocupa también un muy destacado lugar, de forma que un postre muy típico entre los judíos españoles de época medieval, así como entre sus descendientes sefardíes, son las rosquillas, que se consumían en los días festivos y con ocasión de celebraciones importantes, como circuncisiones o bodas. Se elaboraban a base de harina, huevos, aceite y azúcar, siendo habitual el añadido de anises; una vez que se freían en la sartén, se cubrían con azúcar. En ocasiones se elaboraban algunas variantes, añadiendo almendras, queso, azafrán o especias diversas ${ }^{114}$. En general, la repostería judeoespañola y sefardí concedía gran importancia a la harina, a los huevos, a los frutos secos, a la miel y a la canela, siendo mucho más frecuentes los dulces elaborados a base de estos productos que los que utilizaban productos lácteos, que, por el contrario, predominaban más en el mundo ashkenazí.

\section{El vino en la alimentación cotidiana de los judíos en la Edad Media}

Lo mismo que el cereal, el vino constituye otro de los ingredientes fundamentales en la dieta cotidiana del hombre medieval, a la que aportaba buen número de calorías. Por este motivo, a lo largo de la Edad Media el vino fue un producto de primera necesidad, y a partir de los siglos XII y XIII se transformó en un importante objeto de transacción mercantil. De este modo, en las regiones de la Europa mediterránea el vino era la bebida más elaborada y la más consumida después del agua, no faltando a diario ni en la mesa de los ricos ni en la de los pobres; su con-

${ }^{113}$ Miguel Ángel MOTIS DOLADER, María Gloria DÍAZ BARÓN, Francisco JAVIER PASCUAL y Luisa María SÁNCHEZ ARAGONÉS, «Régimen alimentario de las comunidades judías y conversas en la Corona de Aragón en la Edad Media», en Col.loqui d'Història de l'Alimentació a la Corona d'Aragó. Lleida. Institut d’Estudis llerdencs, 1995, págs. 205-361 (véase pág. 344).

114 Idem, págs. 348-349. 
sumo era bastante más elevado entonces que en la actualidad, tanto entre los cristianos ${ }^{115}$ como entre los judíos ${ }^{116}$.

Pero, además del destacado lugar que ocupaba en la alimentación cotidiana, el vino era también un elemento imprescindible en la liturgia cristiana, y entre los judíos, como hemos tenido ocasión de comprobar, constituye un ingrediente básico en la celebración de la cena del shabat, así como en el ritual propio de algunas de las fiestas más importantes del calendario litúrgico judío, como en el séder de Pésah. En último extremo, el vino tenía también en la Edad Media un uso terapéutico de primera importancia, siendo utilizado como antiséptico y para la preparación de numerosos fármacos; y no menos destacable era su función social, de forma que servía para acompañar el tiempo libre, como elemento de distracción y evasión, ayudando a potenciar las relaciones familiares y sociales.

Por lo que en concreto se refiere al vino consumido por los judíos - conocido en la documentación medieval castellana como «vino judiego», y como «vi jueusc» en la del área lingüística catalana-, la legislación hebraica ordenaba la observancia de una precisa normativa para que el vino tuviera la consideración de kasher, es decir para que fuera apto para el consumo por parte de los judíos ${ }^{117}$. En cualquier caso, todo permite suponer que las prescripciones relativas al vino eran bastante menos rígidas que por lo que respecta a otros alimentos, principalmente la carne ${ }^{118}$, de forma que en casos de necesidad se recurría, sin excesivo escándalo por parte de las autoridades rabínicas, al vino elaborado por cristianos.

Pero, por norma general, para que el «vino judiego» sea kasher, es necesario que en su proceso de elaboración no intervenga ningún gentil. Esta prescripción es muy antigua y obedece en sus orígenes, con toda probabilidad, al deseo de evitar el consumo por parte de los israelitas de vino consagrado a los ídolos, teniendo en cuenta la costumbre muy extendida entre los pueblos paganos del Próximo Oriente de ofrecer vino como libación en honor de sus dioses. Para algunos autores, la permanencia de esta prescripción en época medieval tendría mucho que ver con el lugar fundamental que el vino tiene en la liturgia cristiana de la misa.

Pero garantizar que en el proceso de elaboración del vino no interveniera ningún cristiano, ni siquiera de forma indirecta, no era fácil. Así, en unas responsa que

\footnotetext{
115 Se calcula que el consumo de vino en la Bolonia de los siglos X al XIV era de unos dos hectólitros por persona al año, lo que equivaldría a algo más de medio litro por persona al día (Antonio Iván PINI, «La viticoltura italiana nel Medioevo. Cultura della vite e consumo del vino a Bologna dal X al XV secolo», en Studi Medioevali, s. 3, XV (1974), págs. 795-884; véase pág. 873).

${ }^{116}$ Ariel Toaff calcula el consumo de vino en las familias hebreas de la región italiana de la Umbria, en época bajomedieval, entre los seis y los ocho hectólitros al año, lo que equivaldría a un consumo diario de entre un litro y medio y tres litros por familia, es decir alrededor de medio litro por persona y día (Ariel TOAFF, Il vino e la carne. Una comunità ebraica nel Medioevo. Bologna. II Mulino, 1989, págs. 97-98).

117 El término kasher, que quiere decir «apto» o «lícito» en hebreo, hace referencia a todos los alimentos - carne, pescado, queso, vino- que son aptos para el consumo humano, de acuerdo con las prescripciones de la Torá (Levítico, XI, y Deuteronomio, XV).

118 Véase Enrique CANTERA MONTENEGRO, «La carne y el pescado en el sistema alimentario judío en la España medieval», en Espacio, Tiempo y Forma. Serie III. Historia Medieval, 16 (2003), págs. 13-51.
} 
en 1396 dirigía el célebre talmudista y poeta barcelonés Yishaq ben Sheshet Perfet (1326-1408) ${ }^{119}$ al rabí Amran Efratí ben Meru'am de Orán, reconocía la imposibilidad para los judeoconversos de Mallorca y de otras diversas comarcas hispanas de garantizar la condición de kasher del vino que consumían, en particular por lo que hacía referencia al contacto con el mismo de personas cristianas ${ }^{120}$. Pese a todo, las autoridades rabínicas se esforzaban por asegurar el alejamiento de los cristianos en el proceso de elaboración del "vino judiego»; una buena muestra de ello la encontramos en una ordenanza del cabildo catedralicio de Murcia, del año 1476, por la que se prohíbe a los judíos la elaboración del «vino judiego» en el granero mayor en el que se recolectaban los frutos del diezmo eclesiástico, porque

«ellos mismos (los judíos) pisan la uva e guardan el cubo en que las pisan, que no lleguen los christianos a ella después de pisada por ellos; ni menos quieren que tangan (= toquen) los christianos el vino, e si lo tañen derrámanlo, e ante lo quieren perder que no beber; e si lo han de medir con la cántara, no lo medirán fasta que ellos ayan lavado la tal cántara con muchas aguas e muchas vezes, con çeremonias reprobadas en nuestra ley, así como si los christianos fuesen gentes o personas suzias o leprosas» ${ }^{121}$.

Como no podía ser de otro modo, el cuidado que ponían los judíos para que los cristianos no entraran en contacto con el «vino judiego» levantaba entre éstos una fuerte suspicacia y animosidad, porque lo consideraban como algo despreciativo. Así, en el Shébet Yehudah, una crónica hispanohebrea del siglo XVI, de la que es autor Shelomo ben Verga ${ }^{122}$, se trata de justificar en uno de sus capítulos el rechazo por parte de los judíos del vino que había sido tocado por cristianos, argumentando que ello obedece a motivaciones de índole estrictamente religiosa, que nada tenían que ver con una actitud de desprecio hacia los cristianos. En este pasaje del capítulo VII, un rey Alfonso, al que no es posible identificar con ningún monarca concreto castellano, en una conversación que mantenía con un sabio cristiano llamado Tomás, condena la costumbre judía de rechazar el vino tocado por cristianos, por considerarlo una afrenta. Pero el sabio Tomás demuestra al rey Alfonso que este rechazo obedece, exclusivamente, a una prescripción religiosa:

\footnotetext{
119 Originario de Barcelona, ejerció como rabino en su ciudad natal, en Zaragoza y en Valencia; en 1391 hubo de dejar la Península Ibérica, como consecuencia de las persecuciones que sufrieron numerosas comunidades judías hispanas, estableciéndose en Argel, donde fue nombrado dayán o juez de la aljama judía. Sus Responsa son de gran importancia para la historia de los judíos españoles y magrebíes durante el siglo XIV.

120 M.A. MOTIS DOLADER, Ma G. DÍAZ BARÓN, F. JAVIER PASCUAL y L.M ${ }^{a}$ SÁNCHEZ ARAGONÉS, «Régimen alimentario de las comunidades judías y conversas en la Corona de Aragón en la Edad Media», págs. 253-254.

${ }^{121} \mathrm{~F}$. MARSILLA PASCUAL, «Los judíos y el Cabildo catedralicio de Murcia en el siglo XV», en Miscelánea Medieval Murciana, XIV (1990), págs. 44-84.

122 Hay dos ediciones españolas de esta crónica: la de Francisco CANTERA BURGOS, Chébet Jehuda (La Vara de Judá) de Salomón ben Verga. Granada, 1927, y la más reciente de María José CANO, La Vara de Yehudah (Séfer Sebet Yehudah). Barcelona. Riopiedras Ediciones, 1991.
} 


\section{«El rey dijo:}

'Tal vez esas son las razones que provocan el odio. Mas éstos tienen disculpas en ello porque ¿quién obliga a los cristianos a tomar dinero de los judíos con usura?

También considero otra razón: la gran diferencia que tienen con los cristianos en su comer y beber, pues no hay cosa que más aproxime los corazones de los vecinos como la costumbre de comer juntos. Incluso existe un lugar en las islas cuyos juramentos se hacen sobre el pan que todos juntos han comido. Yo juro por nuestro Mesías, que me ha hecho rey, que una vez se encendió mi ira para exterminar el linaje de los judíos o para expulsarlos, porque oí que si cae un bichito en una copa de vino en la que un judío está bebiendo, arroja el bichito y bebe el vino; y si, por el contrario, uno de nosotros ha tocado aquella copa, tira el vino. De donde se deduce que a sus ojos somos considerados como un pueblo inmundo'.

Respondió Tomás:

'Los judíos no tienen en esto culpa, sino los talmudistas, que han puesto cadenas de hierro en sus pies y han dificultado tanto las cosas que no les dejan vivir. En verdad la Biblia dice: « ¿No comían la grasa de sus sacrificios y bebían el vino de sus libaciones?», y no entendieron que se refería a los sacrificios y libaciones que hacían al sol y a la luna antes de que viniese al mundo Jesús. Llegaron los talmudistas diciendo que todo vino que fuera empleado para algún culto en el lugar santo de otros estaba prohibido; todavía restringieron más el caso al declarar que si no se sabía si había sido empleado en las ofrendas del sacrificio, ante la duda, fuera prohibido'.

Dijo el rey:

'Tú has dicho que la culpa es de los talmudistas pero yo afirmo que sólo la tienen los que escuchan sus palabras. En cualquier caso, ahora sé que los judíos en el asunto del vino obran según su Ley'.

Dijo Tomás:

'Así es, sin duda. Ya sucedió en la corte del rey, tu padre, quien dijo a un médico judío que tenía: «He oído que nosotros somos a vuestros ojos inmundos y por eso cuidáis tanto que no toquemos vuestro vino. ¡Obre así Dios con vosotros!» Replicó el médico: «Tú, señor nuestro, estás enfermo y no tengo más empeño que buscar tu curación. ;Traigan agua para lavar los pies de mi señor, porque es necesario! Después contestaré a la pregunta». El médico, después de lavar los pies del monarca, bebió de esa misma agua. Exclamó el rey: “iYa has contestado a mi pregunta!» Los nobles dijeron: «No entendemos». Preguntó el médico: “¿Qué es más inmundo, aquello con que se ha lavado los pies de un hombre o lo que él ha tocado con su mano o su boca? Si el hecho fuese por razón de impureza, ¿cómo había yo de beber el agua del lavatorio?»

El rey Alfonso dijo:

'Hizo bien el médico. Sin duda era de los judíos más inteligentes»' ${ }^{123}$.

${ }^{123}$ María José CANO, La Vara de Yehudah (Séfer Sebet Yehudah), págs. 44-45. 
A causa de la prescripción que prohibía a los judíos el consumo de vino no kasher, las autoridades de las aljamas se interesaron a lo largo de toda la Edad Media por organizar convenientemente los procesos de elaboración y comercialización del vino, consiguiendo asegurarse en diversas localidades una cierta autonomía en las fases de producción y distribución. Del mismo modo, con el fin de asegurarse la disponibilidad de la cantidad de vino precisa para el consumo familiar, eran numerosos los judíos que disponían de viñas de su propiedad o que las arrendaban, principalmente de monasterios, de cabildos y de otras diversas instituciones eclesiásticas. En algunos casos los judíos explotaban directamente las viñas de su propiedad, en tanto que en otras ocasiones, cuando se trataba de personas de condición socio-económica elevada, se ayudaban para ello de obreros o jornaleros, o las daban en arrendamiento a cultivadores judíos o cristianos, a cambio de una renta en numerario y/o en especie. No es infrecuente que se constituyeran sociedades mixtas de agricultores cristianos y productores judíos; en tanto que los primeros atenderían a todas las tareas relativas al cultivo de la vid, hasta que la uva era trasladada al lagar, los judíos se ocuparían de la pisa, del proceso de vinificación y del almacenamiento del vino, con lo que garantizaban la condición de kasher del vino ${ }^{124}$. En algunos casos, incluso, los judíos compraban la uva a agricultores cristianos, lo que tampoco alteraba la condición de kasher del vino; son muy numerosos los contratos de compraventa de uva entre cristianos y judíos que Asunción Blasco ha documentado para la Zaragoza de los siglos XIV y $X V$. Estos contratos se suscribían, habitualmente, en los meses de agosto y septiembre, en las fechas inmediatamente anteriores a la vendimia; los compradores solían ser judíos que, de este modo, se aseguraban la cantidad de vino precisa para el consumo familiar ${ }^{125}$.

El proceso de elaboración del «vino judiego» no difería, sustancialmente, del proceso de elaboración del «vino christianiego», si bien aquél era muy apreciado en época medieval porque no admitía ningún tipo de aditivos que, como la cal o el yeso, eran bastante habituales a fin de reducir la acidez. De acuerdo con las técnicas propias de la Edad Media, la elaboración del vino se iniciaba con la pisa de la uva; cuando el mosto fermentaba lo suficiente en el lagar, se vertía en cubas o toneles, generalmente de roble, que se depositaban en el sótano de la vivienda, que hacía las veces de almacén y bodega. Para la distribución del «vino judiego» entre la comunidad hebrea, las aljamas disponían de una taberna en la judería, donde podrían adquirirlo «por menudo» todos aquellos judíos que no dispusieran de vino de elaboración propia.

Los tipos de caldos variaban de unas a otras comarcas, en función de la materia prima disponible y de las costumbres regionales. Si las fuentes de la Antigüedad hacen referencia a una gran variedad de tipos de vino elaborado por los ju-

\footnotetext{
${ }^{124}$ Asunción BLASCO MARTÍNEZ, «La producción y comercialización del vino entre los judíos de Zaragoza (siglo XIV)», en Anuario de Estudios Medievales, 19 (1989), págs. 405-449 (véase pág. 419).

125 Idem.
} 
díos - tinto, blanco, puro/claro, nuevo/fresco, viejo, dulce, agrio/ácido, amargo y cocido ${ }^{126}$-, la documentación medieval distingue, básicamente, entre vino tinto y vino blanco, otorgándose prioridad al vino tinto sobre el blanco para pronunciar la bendición del vino (quidús) en la cena que da comienzo a la fiesta del shabat, así como en el séder de Pésah.

Al igual que los concejos, las aljamas judías se interesaron por regular de forma minuciosa, en el marco concreto de la judería, todos los aspectos relativos al proceso de distribución y comercialización del vino. En los siglos de la Plena Edad Media, las autoridades regias concedieron libertad de actuación a las aljamas en esta materia, de forma que sólo intervenían en los casos especialmente conflictivos. Sin embargo en la Baja Edad Media, y debido en buena medida a la autorización concedida a las aljamas para la percepción de sisas sobre el consumo del vino y de la carne, los oficiales regios intervinieron con mayor asiduidad con disposiciones aparentemente proteccionistas, cuyo objetivo consistía en combatir el fraude ${ }^{127}$. La imposición de sisas por parte de las aljamas requería la previa autorización regia; una vez concedida la preceptiva autorización, el arrendatario de la renta se esforzaba por controlar de forma minuciosa la producción y comercialización del «vino judiego», adoptando las medidas oportunas para evitar que alguien pudiera evadir esta contribución ${ }^{128}$.

Sin embargo, y pese a la estrecha vigilancia que ejercían, no era fácil para los oficiales de las aljamas evitar fraudes como la introducción subrepticia de «vino judiego" foráneo que, al no estar cargado con las correspondientes sisas, podía ser vendido a un precio inferior, lo que perjudicaba a los productores locales. ${ }^{129} \mathrm{El}$ fraude se combatía mediante la imposición de fuertes sanciones económicas a los taberneros y a los comerciantes que actuaban de forma ilegal, llegando a imponerse en ocasiones especialmente graves la pena de excomunión mayor (hérem) ${ }^{130}$.

${ }^{126}$ M.A. MOTIS DOLADER, Mª G. DÍAZ BARÓN, F. JAVIER PASCUAL y L. Mª SÁNCHEZ ARAGONÉS, «Régimen alimentario de las comunidades judías y conversas en la Corona de Aragón en la Edad Media», pág. 255, nota 328 (según S.M. PAUL, «Classifications of wine in Mesopotamian and rabbinic sources», en Israel Exploration Journal, 25 (1975), págs. 42-44).

127 Asunción BLASCO MARTÍNEZ, Op. cit., pág. 429.

${ }^{128}$ La sisa recaía directamente sobre el vendedor del producto quien, a su vez, estaba autorizado a hacerla repercutir sobre el comprador, mediante merma en la medida del producto. Con el tiempo, este sistema de percepción fue suplido por la imposición de una sobretasa en el precio.

129 En 1370, y a petición de la aljama judía de Zaragoza, el rey Pedro IV de Aragón prohibía la introducción fraudulenta de vino foráneo en la judería zaragozana, y autorizaba a las autoridades comunales judías la imposición de multas y de penas espirituales a los judíos que incurrieran en este delito (Asunción BLASCO MARTÍNEZ, Op. cit., pág. 430).

${ }^{130} \mathrm{Al}$ ser considerado como un acto legal, el hérem era pronunciado por el tribunal rabínico de la aljama para castigar los delitos especialmente graves: agresiones y amenazas, incumplimiento de obligaciones fiscales, falso testimonio y, muy en particular, transgresión de un mandato religioso especialmente importante y delación o calumnia de un correligionario judío ante las autoridades civiles (malsindad). El hérem conllevaba el apartamiento de la comunidad religiosa durante un período de tiempo indefinido, y ni parientes ni amigos podían relacionarse durante ese tiempo con el "excomunicado". Se pronunciaba de forma solemne desde lo alto de la tribuna sinagogal (bimá), en presencia de la mayor parte de los miembros de la comunidad. 
Por otra parte, los concejos dictaban con frecuencia prohibiciones a los taberneros judíos para vender «vino judiego» a los cristianos, y establecían penas pecuniarias para los cristianos que acudieran a comprar vino a la taberna de la judería. Esta prohibición respondía, con toda probabilidad, a una doble motivación: por una parte, a un decidido propósito de impedir que los cristianos consumieran alimentos propios de los judíos, y por otra al deseo de evitar fraudes en relación con las sisas concejiles sobre el consumo de vino. Un buen ejemplo de esta forma de actuar lo encontramos en la localidad riojana de Haro, en la que el 24 de marzo de 1490 el concejo acordaba que «... por quanto algunas personas iban por vino a la judería, et esto hera contra nuestros usos et costunbres, et aún contra nuestra Ley, mandaron que ninguno non sea osado de ir por vino a la judería, so pena de cada uno que se probare que ba por el dicho vino a la judería que pague por cada vez sesenta maravedíes, et, segund manda la Ley de Postura, con los días en la torre» ${ }^{131}$.

En la Baja Edad Media la percepción de sisas sobre el consumo de vino estaba generalizada, y al menos desde la segunda mitad del siglo XIV las aljamas se esforzaron por aprobar disposiciones de carácter proteccionista que prohibían la entrada de «vino judiego» foráneo sin el previo consentimiento del consejo de la aljama. En cualquier caso, la autorización para introducir vino foráneo estaba siempre supeditada al pago de las sisas correspondientes, así como a la falta de existencias de vino de la propia comarca. De este modo, a lo largo de la Baja Edad Media las aljamas judías regularon de forma minuciosa los más diversos aspectos relativos a la comercialización del «vino judiego», a cuyo fin dictaron disposiciones con las que trataban de prevenir y combatir el fraude, así como de potenciar el consumo del vino elaborado por los judíos pecheros de la localidad.

Por el contrario, las aljamas judías recibían con frecuencia privilegios de los monarcas en los que se les autorizaba la importación de "vino judiego» foráneo cuando el de producción propia no era suficiente para cubrir las necesidades de la comunidad hebrea, independientemente de que aún pudieran existir en la localidad existencias de «vino christianiego» ${ }^{132}$. Este privilegio se fundamentaba en la prohibición para los judíos de consumir vino en cuyo proceso de elaboración hubieran intervenido gentiles. Estas licencias daban lugar algunas veces a colisiones entre los derechos de las aljamas para introducir «vino judiego» foráneo y los privilegios de los concejos para que no se introdujera vino de fuera de la comarca sino en circunstancias muy especiales, lo que obligaba a un arbitraje por parte de las autoridades jurisdiccionales correspondientes. Es interesante a este respecto el litigio que se planteó en el año 1353 entre el consell y la aljama de los judíos de Lérida, ya que si los judíos ilerdenses gozaban de un antiguo privilegio que les permitía la

${ }^{131}$ Archivo Municipal de Haro, Actas Municipales, leg. 57, letra AB.

${ }_{132}$ En 1316 el rey Jaime II de Aragón concedía licencia a la aljama de los judíos de Tarazona para introducir cada año hasta treinta cargas de "vino judiego" foráneo (M.A. MOTIS DOLADER, Ma G. DÍAZ BARÓN, F. JAVIER PASCUAL y L.Ma SÁNCHEZ ARAGONÉS, Op. cit., pág. 256, nota 332). 
importación de «vino judiego» foráneo sin ningún tipo de limitaciones, los campesinos de la misma localidad habían obtenido en 1353 un privilegio del rey Pedro IV de Aragón para que nadie pudiera introducir en la ciudad vino foráneo, desde la vendimia hasta la fiesta de Santa María Magdalena, el 22 de julio, al final ya del año vitícola. Como era habitual en estos casos, el conflicto hubo de resolverse mediante un compromiso o sentencia arbitral ${ }^{133}$.

De este modo, el consumo de vino no sólo estaba autorizado por la religión judía sino que, con frecuencia, los rabinos de época medieval insistían acerca de los beneficios que para la salud se seguían de una ingesta moderada de vino. Sin embargo, se condena el abuso del vino hasta la ebriedad, lo que se considera una abominación, porque impide trabajar, conduce a la indigencia y transforma al hombre sabio en un insensato. Sólo se autoriza a beber sin límite con ocasión de la fiesta de Purím, en la que, en un ambiente de gran alegría, se conmemora la liberación de los judíos de Persia por mediación de la reina Ester, casada con el rey persa Asuero ${ }^{134}$. La favorable opinión de los rabinos hacia el vino se impuso sin grandes dificultades a los criterios preconizados por algunas corrientes ascéticas y pietistas que defendían la abstinencia en el consumo de vino y carne, como manifestación de dolor por la destrucción del Templo de Jerusalén y por el exilio de la Tierra de Promisión.

133 Jaume RIERA I SANS, Op. cit., pág. 304.

${ }^{134}$ La fiesta de Purím se celebra el día 14 del mes de adar, y en ella se conmemora la liberación de los judíos por parte de la reina Ester quien, alentada por su tío Mardoqueo, frustró el complot urdido por el primer ministro Amán para destruir a la comunidad hebrea. 